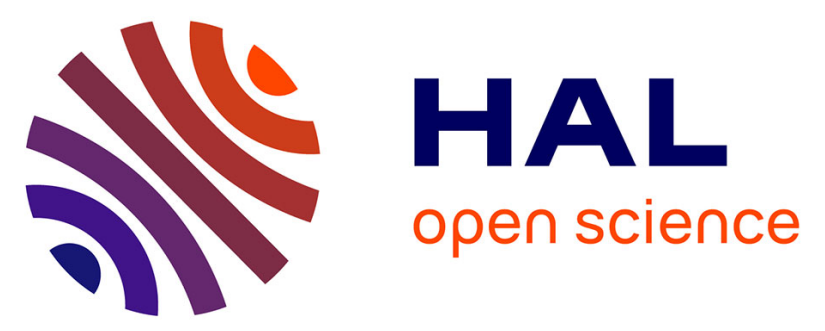

\title{
Dating late Holocene lava flows in Pico de Orizaba (Mexico) by means of in situ-produced cosmogenic 36Cl, lichenometry and dendrochronology
}

Jesús Alcalá-Reygosa, David Palacios, Irene Schimmelpfennig, Lorenzo

Vázquez-Selem, Leopoldo García-Sancho, Osvaldo Franco-Ramos, José

Villanueva, José Juan Zamorano, Georges Aumaitre, Didier Bourles, et al.

\section{To cite this version:}

Jesús Alcalá-Reygosa, David Palacios, Irene Schimmelpfennig, Lorenzo Vázquez-Selem, Leopoldo García-Sancho, et al.. Dating late Holocene lava flows in Pico de Orizaba (Mexico) by means of in situ-produced cosmogenic $36 \mathrm{Cl}$, lichenometry and dendrochronology. Quaternary Geochronology, 2018, 47, pp.93-106. 10.1016/j.quageo.2018.05.011 . hal-01795226

\section{HAL Id: hal-01795226 \\ https://hal.science/hal-01795226}

Submitted on 3 May 2019

HAL is a multi-disciplinary open access archive for the deposit and dissemination of scientific research documents, whether they are published or not. The documents may come from teaching and research institutions in France or abroad, or from public or private research centers.
L'archive ouverte pluridisciplinaire HAL, est destinée au dépôt et à la diffusion de documents scientifiques de niveau recherche, publiés ou non, émanant des établissements d'enseignement et de recherche français ou étrangers, des laboratoires publics ou privés. 


\section{Dating late Holocene lava flows in Pico de Orizaba (Mexico) by means of in situ- produced cosmogenic ${ }^{36} \mathrm{Cl}$, lichenometry and dendrochronology}

Jesús Alcalá-Reygosa ${ }^{a, *}$, David Palacios ${ }^{b}$, Irene Schimmelpfennig ${ }^{c}$, Lorenzo Vázquez-Selem ${ }^{d}$, Leopoldo García-Sancho ${ }^{e}$, Osvaldo Franco-Ramos ${ }^{d}$, José Villanueva ${ }^{f}$, José Juan Zamorano ${ }^{d}$, ASTER Team (Georges Aumaître ${ }^{g}$, Didier Bourlès $^{g}$, Karim Keddadouche ${ }^{g}$ )

a Facultad de Filosofía y Letras, Universidad Nacional Autónoma de México, Ciudad Universitaria, 04510 Ciudad de México, Mexico

b Departamento de Geografía, Facultad de Geografía e Historia, Universidad Complutense, C/ Profesor Aranguren S/N, 28040, Madrid, Spain

C Aix Marseille Univ, CNRS, IRD, INRA, Coll France, CEREGE, Aix-en-Provence, France

d Instituto de Geografía, Universidad Nacional Autónoma de México, Ciudad Universitaria, 04510 Ciudad de México, Mexico

e Departamento de Biología Vegetal II, Facultad de Farmacia, Universidad Complutense, Plaza de Ramón y Cajal S/N, Ciudad Universitaria, 28040, Madrid, Spain

f INIFAP CENID-RASPA, Km 6,5 Margen Derecha del Canal Sacramento, Gómez Palacio, Durango, Mexico

9 Aix Marseille Univ, CNRS, IRD, INRA, Coll France, CEREGE, Aix-en-Provence, France

\section{A B S TRA C T}

The knowledge of the eruptive history of volcanic centers allows for improving the evaluation of the related risks and hazards in populated areas, but substantially depends on the ability of dating the lava flows. However, traditional methods such as $\mathrm{U}-\mathrm{Th} / \mathrm{He},{ }^{40} \mathrm{Ar}-{ }^{39} \mathrm{Ar},{ }^{40} \mathrm{~K}-{ }^{40} \mathrm{Ar}$ and radiocarbon dating are not always suitable. Therefore, an alternative approach based on the combination of in situ-produced ${ }^{36} \mathrm{Cl}$ based cosmic ray exposure dating, lichenometry and dendrochronology was tested on two lava flows (called Lava flow "A" and "B") from Pico de Orizaba (Mexico), previously attributed to 16th and 17th century eruptions, respectively. The presented results show that both lava flows are significantly older than their assumed 16th and 17 th century ages. Regarding lava flow " $A$ ", the measured in situ-produced ${ }^{36} \mathrm{Cl}$ concentrations lead to a mean age of $3.03 \pm 0.70 \mathrm{ka}$, while dendrochronology and lichenometry yield minimum ages of 834 and 1130 years, respectively. Regarding lava flow "B", the measured in situproduced ${ }^{36} \mathrm{Cl}$ concentrations lead to a mean age of $1.45 \pm 0.35 \mathrm{ka}$, whereas lichenometry gives a minimum age of $\sim 1000$ years. Overall, this demonstrates that the combination of in situproduced ${ }^{36} \mathrm{Cl}$ based cosmic ray exposure dating, lichenometry and dendrochronology has a con- siderable potential for dating purposes on young deposits and landforms, in particular on lava flows at high elevation sites. 


\section{Introduction}

Dating lava flows provides new insights into the eruptive history of volcanic centers such as stratovolcanoes, thus allowing for the estima- tion of the related hazards and risks in populated areas. In this sense, dating lava flows over time scales covering the last centuries to the last millennia is important to test models that aim at establishing potential patterns of eruption recurrence and thus to improve the prediction of future eruptions. Moreover, some stratovolcanoes are ice-capped, and better understanding their glacio-volcanic evolution helps evaluating the hazards related to the interaction between ice and volcanic activity (i. e. large debris flows and floods) (Lescinsky and Fink, 2000; Conway et al., 2015; Heineke et al., 2016).

Several methods can be used to date Quaternary lava flows, in- cluding ${ }^{40} \mathrm{Ar}-{ }^{39} \mathrm{Ar}$ (Wijbrans et al., 2011; Conway et al., 2015), ${ }^{40} \mathrm{~K}-{ }^{40} \mathrm{Ar}$ (Germa et al., 2010) radiocarbon (Calvert et al., 2006) and $\mathrm{U}$-Th/He dating (Aciego et al., 2007). However, most of these techniques tend to be unsuitable to date lava flows that were emplaced during the Late Holocene, i.e. during the past $4-5 \mathrm{ka}$. The ${ }^{40} \mathrm{Ar}-$ ${ }^{39} \mathrm{Ar}$ and ${ }^{40} \mathrm{~K}-{ }^{40} \mathrm{Ar}$ dating methods require a detectable concentration of ${ }^{40} \mathrm{Ar}$ (Renne, 2000). Due to its relatively short half-life of 5730 years, radiocarbon can only be used to date lava flows that were emplaced less than $\sim 50$ ka ago. However, for this dating technique, organic material in association with the lava flows is required, which is not always available, especially at high elevations where vegetation is scarce. Nonetheless, radiocarbon dating remains the most commonly used method over this time scale (Trumbore, 2000). The U-Th/He dating method is suitable for dating Late Holocene volcanic rocks, but relies on the presence of atypical volcanic minerals such as garnet, zircon and fayalite with U-rich con- centrations (Aciego et al., 2007). Therefore, alternative methods are needed to determine the age of young lava flows.

Comic ray exposure (CRE) dating, based on measurements of the concentration of in situproduced cosmogenic nuclides such as ber- yllium-10 $\left({ }^{10} \mathrm{Be}\right)$, chlorine-36 $\left({ }^{36} \mathrm{Cl}\right)$ and helium-3 $\left({ }^{3} \mathrm{He}\right)$ in terrestrial surface samples, constitutes a robust method to establish chronological constraints on landform processes (Dunai, 2010). This dating technique relies on the interaction of cosmic ray derived particles with certain target elements in the minerals of the Earth's surface, resulting in steady accumulation of various rare isotopes (in situ in the crystal lattice) with time. The method offers various advantages over others including that it is applicable to time scales between $10^{2}$ and $10^{6}$ years, depending on the preservation state of the lava surface and to a wide range of common rock types and minerals that are present at the Earth's surface.

I. e. ${ }^{10} \mathrm{Be}$ is produced in quartz and can thus be used to date any quartz-

bearing lithology; ${ }^{36} \mathrm{Cl}$ is produced in any $\mathrm{K}$ - and Ca-bearing rocks and minerals and can thus be used to date feldspars, pyroxenes and car- bonates; and ${ }^{3} \mathrm{He}$ can be extracted from olivines, pyroxenes and horn- blendes. To obtain accurate CRE ages, accurate production rates and scaling schemes are required (Dunai, 2010).

As quartz is rarely present in volcanic rocks and ${ }^{10} \mathrm{Be}$ is therefore generally not suited to date lava flows, the measurements of ${ }^{3} \mathrm{He},{ }^{21} \mathrm{Ne}$ or ${ }^{36} \mathrm{Cl}$ in lava flow surfaces are most adequate for dating their em- placements, the choice of the nuclide mostly depending on the rock's mineralogy. In addition, it has been shown that these techniques lead to consistent Holocene ages for the studied volcanic eruptions (Dunbar, 1999; Foeken et al., 2009; Espanon et al., 2014; Fenton and Niedermann, 2014). While ${ }^{3} \mathrm{He}$ and ${ }^{21} \mathrm{Ne}$ have specifically to be ana- lyzed in the pyroxene and olivine phenocrysts of mafic lavas, ${ }^{36} \mathrm{Cl}$ can be extracted from any mineral phase and rock type that contains one or more of its most important target elements, i.e. $\mathrm{Ca}, \mathrm{K}$ and $\mathrm{Cl}$. Moreover, it has been recently shown that reliable ${ }^{36} \mathrm{CI} \mathrm{CRE}$ ages as young as a few hundred years can be obtained for volcanic rocks (Jomelli et al., 2016). Although ${ }^{36} \mathrm{Cl}$ analysis in specific Ca- and/or K-rich minerals, such as feldspars or clinopyroxenes, is preferable to that in volcanic whole rocks because this 
approach generally allows minimizing the $\mathrm{Cl}$ con- centrations that are often very high in the lava matrix (Schimmelpfennig et al., 2009), the absence of sufficient phenocrysts in the lava flows to be dated in this study prevented us to analyze ${ }^{36} \mathrm{Cl}$ in mineral separates. Instead, we used whole rocks to estimate the em- placement age of the lava flows.

Late Holocene lava flows that are exposed at the surface are parti- cularly well suited for CRE dating, because their exposure history is simple and the original surface features are often well preserved al- lowing to reduce the impact of erosion and exhumation on the nuclide inventory (Espanon et al., 2014; Fenton and Niedermann, 2014; Kurz et al., 2014; Medynski et al., 2015; Heineke et al., 2016). Moreover, as lava flows are static surfaces, they are not affected by nuclide in- heritance from previous exposure (Dunai, 2010; Dunai et al., 2014). Due to these advantages, lava flows with ages between 0.4 and up to 250 ka have also been used to obtain ${ }^{3} \mathrm{He}$ and ${ }^{36} \mathrm{Cl}$ production rates (e.g. Cerling, 1990; Schimmelpfennig et al., 2011; Foeken et al., 2012; Schneider et al., 2014).

Dendrochronology and lichenometry are also surface dating methods, based on the start time of colonization by the living organism, which however can lag behind the timing of rock surface formation by an unknown period of time. Therefore, these methods only provide minimum ages and are limited by the organisms' life spans, i.e. gen- erally to the past few hundred years. Dendrochronology is based on the dating of growth rings of woody plants. It has been used for the de- termination of minimum ages of Late Holocene geomorphic surfaces (Shroder and Butler, 1987; Stoffel et al., 2010), including volcano-flu- vial terraces (Pierson, 2007) and post-eruptive ravines (Franco-Ramos et al., 2017). In the mountains of central Mexico, the pine species forming the timberline, Pinus hartwegii, can reach ages of $>500 \mathrm{yr}$ (Villanueva-Díaz et al., 2015). In addition, the alpine juniper shrub Juniperus monticola, which forms annual rings, can live $>800$ years and has high dendrochronological potential (Villanueva-Díaz et al., 2016). Lichenometry is based on a known growth rate of the thalli of li- chens. It has been used since the 1960s for surface dating (Armstrong, 2016). The species Rhizocarpon geographicum has frequently been used because it grows on most of the Earth's mountains and in both circum- polar regions. It exhibits a slow and constant growth rate (Bradwell and Armstrong, 2007). Thus, lichenometry has been widely applied to date glacial and alluvial deposits, slope processes, surfaces affected by tectonics, archeological sites, etc. (Bull, 2015). It is the technique most usually employed to date Late Holocene glacial landforms (Briner, 2011). However, lichenometry has been less used to date volcanic landforms such as lava flows (Clarkson and Clarkson, 1983; Angiel and Dąbski, 2012), lahars and debris avalanches (Crandell et al., 1974), although several studies of lichen colonization have been performed to establish the growth curve on lava flows in tropical (Kurina and Vitousek, 1999), subtropical (Mancebo et al., 1989), temperate (Shimizu, 2004) and polar environments (Talbot et al., 2010). More- over, lichenometry has been combined with other dating methods such as tephrochronology (Beget, 1984; Kirkbride and Dugmore, 2008), radiocarbon dating (Beget, 1984) and dendrochronology (Koch et al., 2007) in volcanic environments to control their surface ages.

Here, we test the combination of the in situ-produced ${ }^{36} \mathrm{Cl}$ based cosmic ray exposure dating (hereafter ${ }^{36} \mathrm{Cl} \mathrm{CRE}$ dating), lichenometry and dendrochronology dating methods to determine the age of two young lava flows on Pico de Orizaba (5675 m a.s.I.), the highest mountain of Mexico, where no numerical dating technique has been applied so far. Lichenometry and dendrochronology allow us to esti- mate minimum ages for both lava flows providing chronological constraints complementary to the ${ }^{36} \mathrm{Cl} \mathrm{CRE}$ ages. Therefore, we think that the combination of these three methods could be an alternative ap- proach to date Late Holocene landforms.

\section{Study area and previous work at Pico de Orizaba}

Pico de Orizaba $\left(19.06^{\circ} \mathrm{N} /-97.25^{\circ} \mathrm{W} ; 5675 \mathrm{~m}\right.$ a.s.I.) or Citlaltépetl ("mountain of the star" in the 
Náhuatl language) is an ice-capped stratovolcano in the eastern part of the Pliocene-Quaternary Trans- Mexican Volcanic Belt (Fig. 1). This chain, associated with the sub- duction of the Cocos Plate beneath the North American Plate, presents a wide variety of volcanic features such as stratovolcanoes (some of them active, e.g. Popocatépetl and Colima), monogenetic cones, dome complexes, maars and calderas.

Carrasco-Núñez (2000) established a chronology of the eruptions of Pico de Orizaba based on K/Ar dating. According to these studies, the construction of Pico de Orizaba began $\sim 0.65 \mathrm{Ma}$ ago, when a large stratovolcano known as Torrecillas covered folded and faulted Cretaceous sedimentary rocks. This first volcanic stage finished with the collapse of Torrecillas cone between $\sim 0.29$ and $\sim 0.21 \mathrm{Ma}$ ago, fol- lowed by the formation of a caldera and of a large debris avalanche. A second stage, starting $\sim 0.21 \mathrm{Ma}$ ago, involved the formation of the Espolón de Oro cone as well as the genesis of peripheral dacitic domes. The "Espolón de Oro" cone collapsed 20 ka ago, producing another massive debris avalanche.

The last volcanic stage began $\sim 20$ ka ago with the construction of the modern Citlaltépetl cone and peripheral dacitic domes. Dacitic and high-silica andesitic lava flows basically built the Citlaltépetl cone, an edifice rising to $5675 \mathrm{~m}$ a.s.I. Two Plinian eruptions have been reported during the late Pleistocene and Holocene: the first occurred $\sim 13 \mathrm{ka}$ ago and the second 9.0-8.5 ka ago (radiocarbon dating) (Carrasco-Núñez and Rose, 1995; Carrasco-Núñez, 2000; Rossotti and Carrasco-Núñez, 2004). This second event affected all the flanks of the volcano and produced a thick pyroclastic deposit known as the Citlaltépetl ignimbrite. Moreover, the glacier located on the top of the volcano experi- enced several advances during the Late Pleistocene and early Holocene (Vázquez-Selem and Heine, 2011) but most of the associated glacio- geomorphic features are covered by the Citlaltépetl ignimbrite and lava flows and pyroclastic layers emitted during the Late Holocene. 


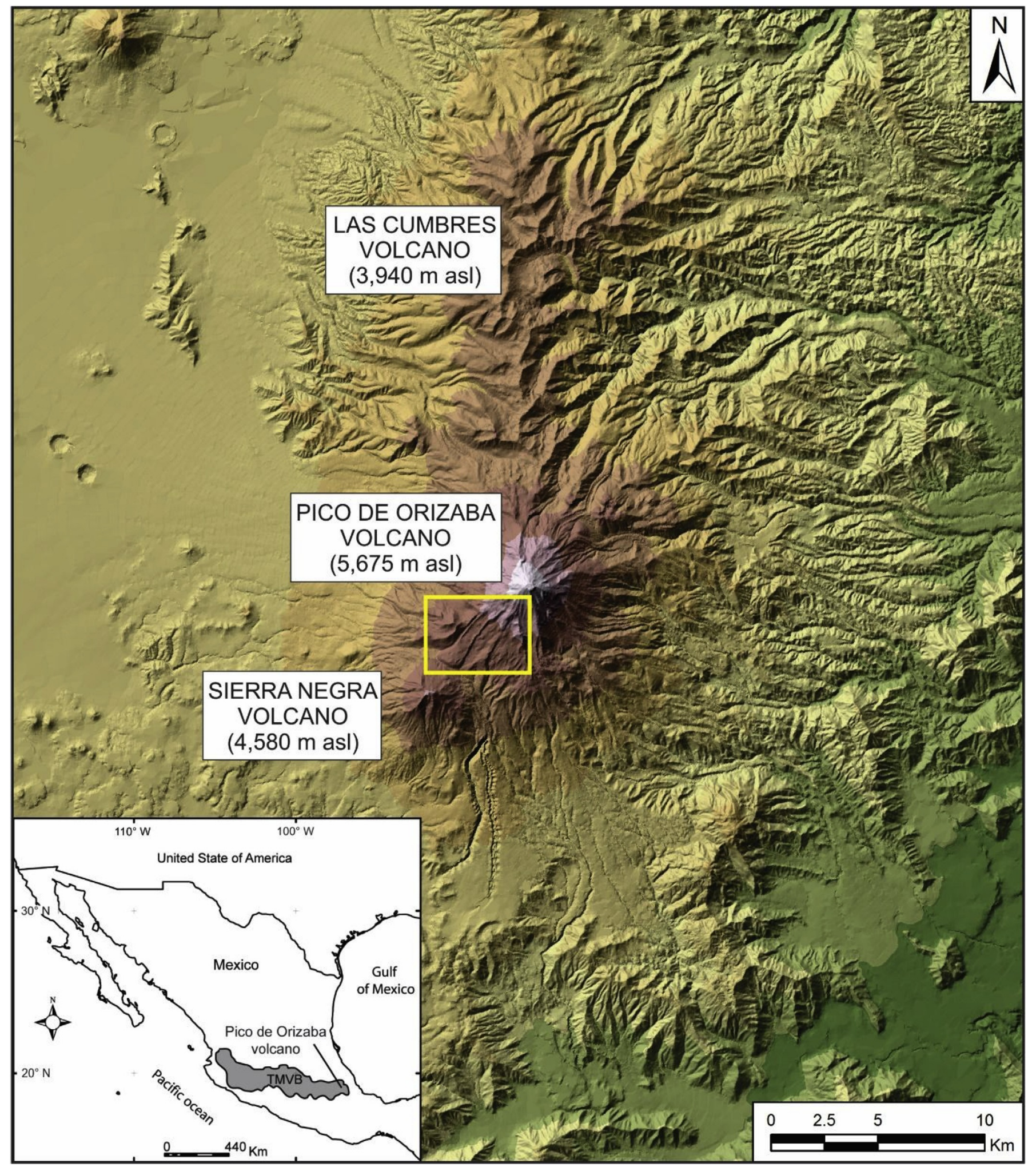

Fig. 1. Location of the study area. Pico de Orizaba, the highest stratovolcano of Mexico, is situated in the eastern part of the Trans-Mexican volcanic belt (TMVB). 
Another significant explosive event took place 4.1-4.0 ka ago (radiocarbon dating) on the western flank of the volcano. Due to the eruption of dacitic lavas, blocks, ash flows and lahars were produced at the summit crater and channelized by a glacial cirque into a valley (Siebe et al., 1993). Other Holocene volcanic events occurred at 7020-6200 ka, 3450-3400 ka (The Jacal volcanic episode) and 1910-1860 years BP (Texmola volcanic episode) (radiocarbon dating) (Höskuldsson and Robin, 1993).

Although volcanic activity has not been reported over the last years, Pico de Orizaba is still an active volcano. Several lava flows have been assigned to Holocene eruptions, including historical activity such as the one known as the Excola eruptive episode ( 1300-1687 AD) (Höskuldsson and Robin, 1993; Carrasco-Núñez, 1997). On the basis of the morphology and structure of these lava flows, Carrasco-Núñez (1997) defined and mapped four categories: (i) single, channeled flows with well-defined lateral levees; (ii) single, blocky flows with lateral levees, rugged top surfaces and steep fronts; (iii) multiple blocky lava flows that sometimes exhibit lateral levees; (iv) massive lava flow fields, including single and multiple flows that present lateral levees and blocky surfaces. The two lava flows dated in this work, informally named here "A" and "B" (Fig. 2), belong to the second group described above. Both moved from the crater to the southwest of the modern cone. They are porphyritic dacites, showing a variation in silica content from 60 to $66 \mathrm{wt} \%$, and their volumes have been estimated at $130 \times 10^{6} \mathrm{~m}^{3}$ for lava flow "A" and $38 \times 10^{6} \mathrm{~m}^{3}$ for lava flow "B" (CarrascoNúñez, 1997). Based on their distribution, morphology and stratigraphic relationships, CarrascoNúñez (1997) suggested that lava flow "A" possibly corresponded to one of the three historically con- firmed eruptions during the 16th century (1537; 1545 or 1566 AD), and lava flow "B" corresponded to the eruption of 1613 AD. Similarly, Höskuldsson and Robin (1993) tentatively ascribed lava flow "A" to the eruption of 1545 AD, and lava flow "B" to that of 1613 AD. The three methods used in this study should allow validating or disproving these assignations.

The climate of the study area, located at altitudes between 4000 and $4500 \mathrm{~m}$ a.s.l, is characterized by relatively cold temperatures and moderate precipitations. According to Lauer (1978), temperatures do not change significantly during the year; the mean annual temperature being $\sim 5{ }^{\circ} \mathrm{C}$ at $4000 \mathrm{~m}$ a.s. I and $0{ }^{\circ} \mathrm{C}$ at $5000 \mathrm{~m}$ a.s.I. The mean number of days with frost is 200 and 360, respectively. Mean annual pre- cipitation ranges from $\sim 900$ (4000 m a.s.l) to $\sim 800 \mathrm{~mm}(5000 \mathrm{~m}$ a.s.l), with most of it occurring during the wet season (May-October) and during some weeks in winter associated with cold fronts coming from higher latitudes. The vegetation is mainly Pinus hartwegii tree stands, the timberline being at $\sim 4000 \mathrm{~m}$ a.s.l, and tufted grass associations of Calamagrostis tolucensis, Festuca tolucensis and Muehlenbergia quadridenta from $\sim 4000$ to $\sim 4400 \mathrm{~m}$ a.s.I.

The front and lateral walls of the lava flow "A", at $4000 \mathrm{~m}$ a.s.l, are covered by Pinus hartwegii tree stands. They become sparser on the top surface of the lava flow with isolated individuals reaching $4300 \mathrm{~m}$ a.s.I. Lava flow "A" is also colonized by individuals of the alpine woody shrub Juniperus monticola, a krummholz species that can grow at ele- vations up to $\sim 4500 \mathrm{~m}$ a.s.l. This woody shrub has been considered as a species with high dendrochronological potential, because of its annual growth rings and a lifetime of hundreds of years (Villanueva-Díaz et al., 2016). In contrast, lava flow "B" (front at 4450 m a.s.I) lacks these woody species since the altitude is higher. However, the rock surfaces of both lava flows are widely colonized by various lichen species including Rhizocarpon geographicum. 


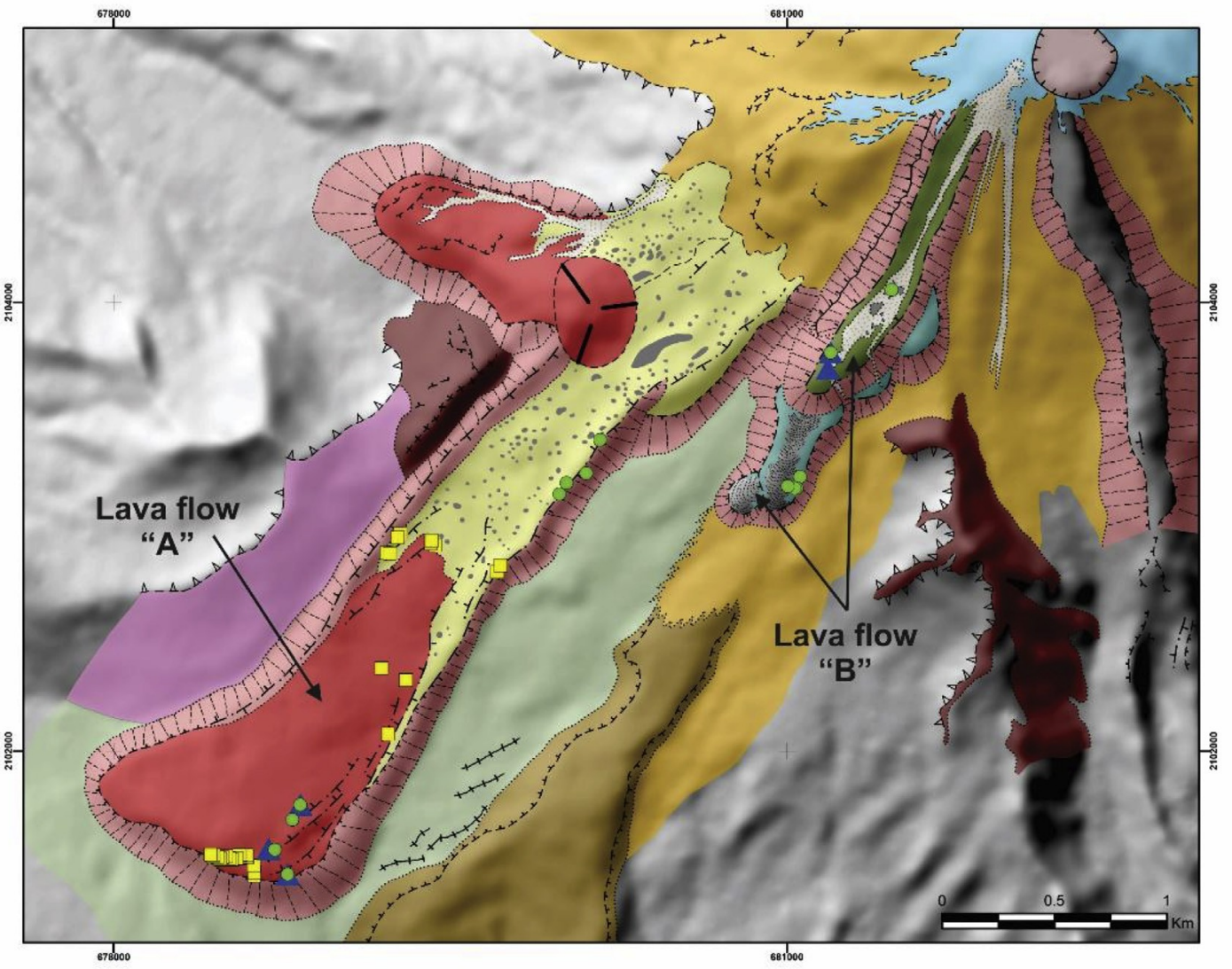

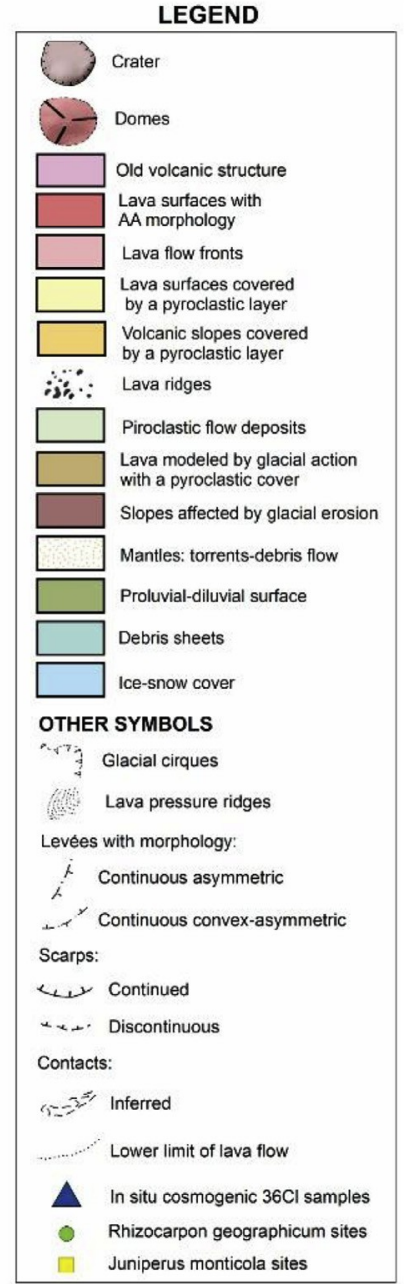

Fig. 2. Geomorphological map from the southwestern slope of Pico de Orizaba. The location of the samples collected for in situ-produced ${ }^{36} \mathrm{Cl} \mathrm{CRE}$ dating, liche- nometry ("Rhizocarpon geographicum sites") and dendrochronology (Juniperus monticola sites) on both lava flows is shown. 


\section{Materials and methods}

\subsection{Geomorphological mapping}

A detailed geomorphological map (scale 1: 10,000) of the south- western flank of Pico de Orizaba volcano was produced from the ana- Iysis of vertical aerial photographs (scale 1:60,000, Instituto Nacional de Estadística y Geografía de México, INEGI). To represent the land- forms in detail, the standard procedures proposed by Bashenina (1977) and Simonov (1972) were used and adapted to the characteristics of the study area. These mapping methods classify the relief based on morphogenetical and morphochronological criteria that include data of li- thology and morphostructures using several colours and areal, lineal and points symbols. The map was verified with fieldwork and then it was digitized using ArcMap 10.2.2 software.

\subsection{In situ-produced ${ }^{36} \mathrm{Cl}$ CRE dating}

\subsubsection{Sampling strategy and analytical methods}

To determine the ${ }^{36} \mathrm{CI} \mathrm{CRE}$ ages of the lava flows, five samples were collected with hammer and chisel from the uppermost $\sim 5 \mathrm{~cm}$ of solid rock surfaces (Fig. 2). Three of them (Pico 4,5 and 6 ) were taken from lava flow A. Pico 4 was collected from the surface of a $>1 \mathrm{~m}$ high, stable boulder on a levee on the left margin of the lava flow, whereas Pico 5 and Pico 6 came from the surfaces of tumuli features situated on the top of the lava flow (Fig. 3). The other two samples (Pico 7 and Pico 8) were collected from the surfaces of prominent tumuli located on the surface of lava flow $B$ (Fig. 4). The field data and sample characteristics of the five samples are given in Table 1. All sampled surfaces were well preserved, showing no signs of erosion, weathering or boulder toppling. Therefore, potential bias in the ${ }^{36} \mathrm{Cl}$ surface concentrations induced by these post-cooling geomorphological processes are minimized. More- over, the protruding geometries of the sampled features reduce the risk of surface shielding by snow, tephra fall associated with volcanic ac- tivity of Pico de Orizaba, and soils.

Lichens, mosses and other organic matter were removed from the samples with a brush. Then, whole rock samples were crushed with a roller grinder and sieved to retrieve the grain size fraction $(0.25-0.50 \mathrm{~mm})$ at Instituto de Geofísica of the Universidad Nacional Autónoma de México (UNAM). The chemical preparation was carried out at the Centre Européen de Recherche et d'Enseignement des Géosciences de l'Environnement (CEREGE; France). Aliquots of the bulk rock were taken for the analyses of the major and trace element con- centrations at Activation Laboratories (Ancaster, Canada) (Table 2), needed to compute the low-energy neutron flux in the samples, which induces the ${ }^{36} \mathrm{Cl}$ production from capture of the low-energy neutrons on ${ }^{35} \mathrm{Cl}$. These bulk rock analyses also allowed us to confirm the dacitic composition of the rock samples (see section 2); i.e. $\mathrm{SiO}_{2}$ concentrations of $\sim 64 \%$ and $\mathrm{Na}_{2} \mathrm{O}+\mathrm{K}_{2} \mathrm{O}$ concentrations of $\sim 6.5 \%$ correspond to a dacite according to the "total alkalies versus silica" classification by Le Bas et al. (1986).

About $80 \mathrm{~g}$ of the sample grains were washed in ultrapure water to remove fine-grained powder and then leached in a dilute $\mathrm{HF} / \mathrm{HNO}_{3}$ mixture to dissolve $\sim 15-20 \%$ of the initial sample mass to remove atmospheric ${ }^{36} \mathrm{Cl}$ and reduce the potentially $\mathrm{Cl}$-rich groundmass (Schimmelpfennig et al., 2009). Then, these etched samples were dried and $2 \mathrm{~g}$ aliquots of each sample were taken for analysis of the major elements at the Activation Laboratories (Ancaster, Canada) (Table 3), because $\mathrm{Ca}, \mathrm{K}, \mathrm{Ti}$ and $\mathrm{Fe}$ are the target elements for ${ }^{36} \mathrm{Cl}$ production by spallation $(\mathrm{Ca}, \mathrm{K}, \mathrm{Ti}, \mathrm{Fe})$ and muon capture $(\mathrm{Ca}, \mathrm{K})$. Before total sample dissolution of the remaining sample material $(\sim 60$ g) in a dilute $\mathrm{HF} / \mathrm{HNO}_{3}$ mixture, $a^{35} \mathrm{Cl}$-enriched spike ( $\left.\sim 99 \%\right)$ was added to each sample and to one chemistry blank for isotope dilution (Ivy-Ochs et al., 2004). The subsequent steps of $\mathrm{AgCl}$ 
precipitations and removal of sulfur were performed according to the methods described in Schimmelpfennig et al. (2011). Both the ${ }^{36} \mathrm{Cl} /{ }^{35} \mathrm{Cl}$ and ${ }^{35} \mathrm{Cl} /{ }^{37} \mathrm{Cl}$ ratios, measured in the year 2015 by AMS isotope dilution at the French national AMS facility (CEREGE, France) (Arnold et al., 2013), were normalized to standard KNSTD1600 (Sharma et al., 1990) with an assigned ${ }^{36} \mathrm{Cl} /{ }^{35} \mathrm{Cl}$ ratio of $(2.112 \pm 0.905) \times 10^{-12}$, and assuming a natural ratio of 3.127 for the ${ }^{35} \mathrm{Cl} /{ }^{37} \mathrm{Cl}$ ratio. From these ratios, the ${ }^{36} \mathrm{Cl}$ and $\mathrm{Cl}$ concentrations were calculated. The analytical data are presented in Table 4.

\subsection{2. ${ }^{36} \mathrm{Cl}$ CRE age calculations}

We calculated the ${ }^{36} \mathrm{Cl} \mathrm{CRE}$ ages according to the formalism pro- posed by Schimmelpfennig (2009) and Schimmelpfennig et al. (2009). The results shown in Table 4 and discussed below are based on the following ${ }^{36} \mathrm{Cl}$ production rates and parameters, referenced to sea level and high latitude, using the time-invariant "St" scaling (Stone, 2000):

$42.2 \pm 4.8$ atoms ${ }^{36} \mathrm{Cl}(\mathrm{g} \mathrm{Ca})^{-1} \mathrm{yr}^{-1}$ for spallation of Ca (Schimmelpfennig et al., 2011), 148.1 \pm 7.8 atoms ${ }^{36} \mathrm{Cl}(\mathrm{g} \mathrm{K}){ }^{-1} \mathrm{yr}^{-1}$ for spallation of $\mathrm{K}$ (Schimmelpfennig et al., 2014), $13 \pm 3$ atoms ${ }^{36} \mathrm{Cl}\left(\mathrm{g} \mathrm{Ti}^{-1} \mathrm{yr}^{-1}\right.$ for spallation of Ti (Fink et al., 2000), $1.9 \pm 0.2$ atoms ${ }^{36} \mathrm{Cl}(\mathrm{g} \mathrm{Fe})^{-1} \mathrm{yr}^{-1}$ for spallation of $\mathrm{Fe}$ (Stone et al., 2005), and $696 \pm 185$ neutrons (g air) ${ }^{-1} \mathrm{yr}^{-1}$ at the Earth's surface/atmosphere interface for the production rate of epithermal neutrons from fast neutrons in the atmosphere (Marrero et al., 2016). Applying the ${ }^{36} \mathrm{Cl}$ production rates from $\mathrm{Ca}$ and $\mathrm{K}$ spallation calibrated by Marrero et al. (2016) of $52.2 \pm 5.2$ atoms ${ }^{36} \mathrm{Cl}(\mathrm{g} \mathrm{Ca})^{-1} \mathrm{yr}^{-1}$ and $150 \pm 15$ atoms ${ }^{36} \mathrm{Cl}$ $(\mathrm{g} \mathrm{K})^{-1} \mathrm{yr}^{-1}$, respectively, yields ${ }^{36} \mathrm{Cl} \mathrm{CRE}$ ages that are insignificantly younger $(<3 \%)$.

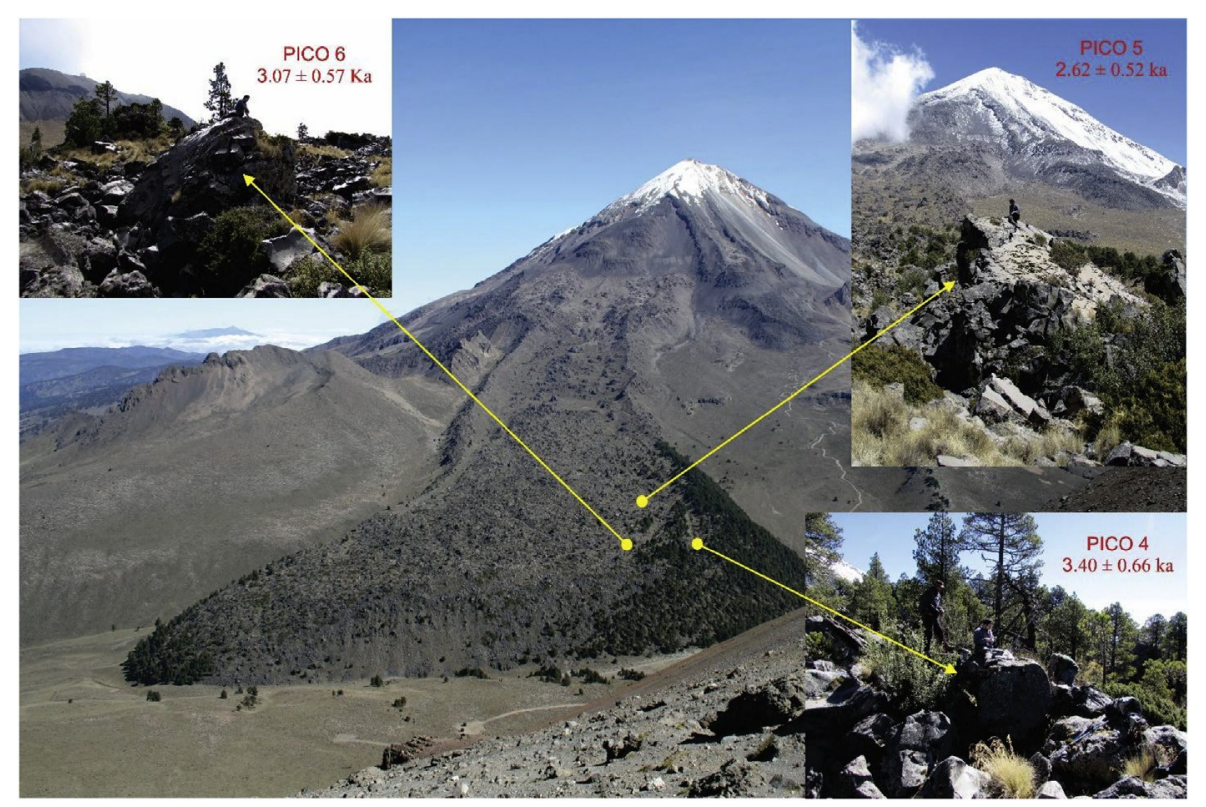

Fig. 3. Locations, photographs and ${ }^{36} \mathrm{Cl} C R E$ ages of the geomorphic features sampled for in situ-produced ${ }^{36} \mathrm{Cl} \mathrm{CRE}$ dating on lava flow "A". 


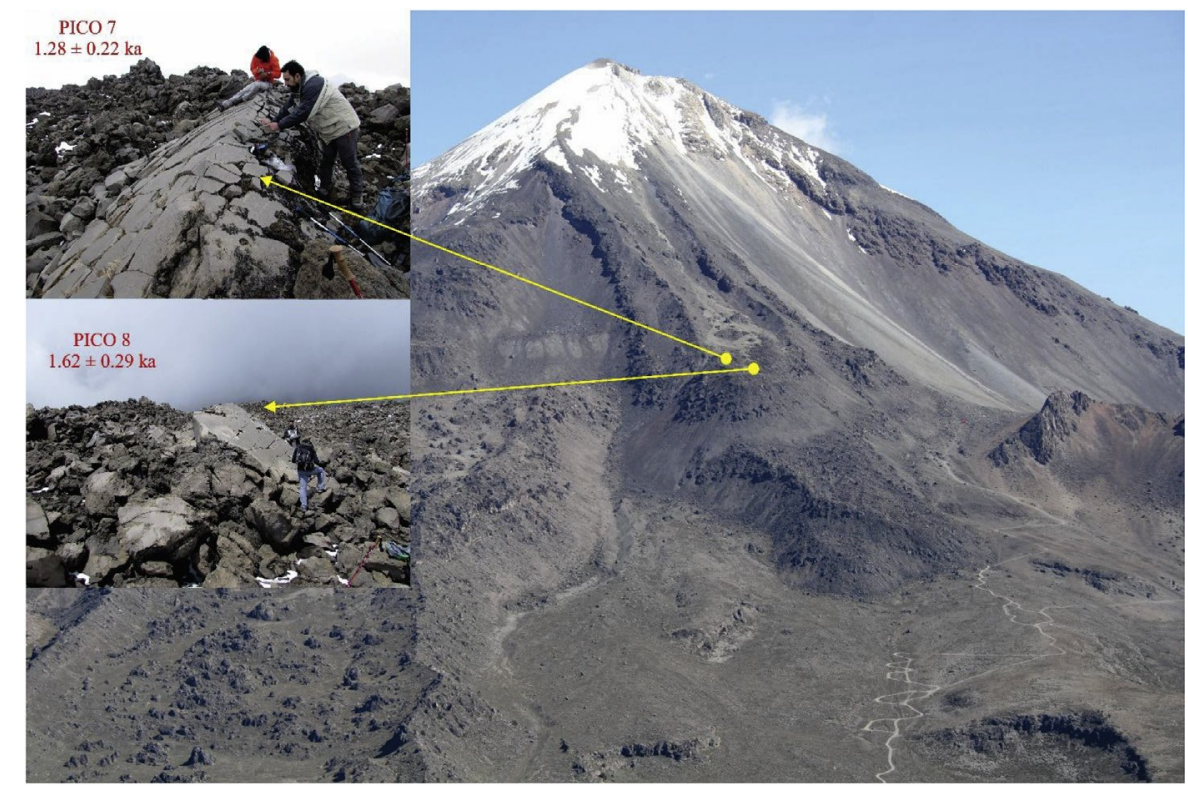

Fig. 4. Locations, photographs and ${ }^{36} \mathrm{Cl} C R E$ ages of the geomorphic features sampled for in situ-produced ${ }^{36} \mathrm{Cl}$ CRE dating on lava flow "B".

Table 1

Field data and sample characteristics of ${ }^{36} \mathrm{Cl}$ dated samples from lava flows of Pico de Orizaba. The shielding factor was calculated using the Topographic Shielding Calculator v1.0 provided by CRONUS-Earth Project (2014).

\begin{tabular}{llllll}
\hline Sample & Latitude & Longitude & $\begin{array}{l}\text { Altitude } \\
\text { (m.a.s.l) }\end{array}$ & Thickness $(\mathrm{cm})$ & $\begin{array}{l}\text { Shielding } \\
\text { factor }\end{array}$ \\
Pico 4 & 18.99 & -97.30 & 4144 & 1.5 & 0.9945 \\
Pico 5 & 19.00 & -97.30 & 4165 & 1.5 & 0.995 \\
Pico 6 & 18.99 & -97.30 & 4166 & 3.0 & 0.9968 \\
Pico 7 & 19.01 & -97.27 & 4831 & 4.0 & 0.9931 \\
Pico 8 & 19.01 & -97.28 & 4815 & 2.0 & 0.9782 \\
\hline
\end{tabular}

Table 2

Major and trace element concentrations in bulk rock samples from lava flows of Pico de Orizaba, before chemical treatment (see text). Analyses done at Activation Laboratories (Ancaster, Canada).

\begin{tabular}{|c|c|c|c|c|c|c|c|c|c|c|c|c|c|c|c|c|c|}
\hline Sample & $\begin{array}{l}\mathrm{SiO}_{2} \\
\text { (wt-\%) }\end{array}$ & $\begin{array}{l}\mathrm{Na}_{2} \mathrm{O} \\
(w t-\%)\end{array}$ & $\begin{array}{l}\mathrm{MgO} \\
\text { (wt- } \\
\%)\end{array}$ & $\begin{array}{l}\mathrm{Al}_{2} \mathrm{O}_{3} \\
\text { (wt-\%) }\end{array}$ & $\begin{array}{l}\text { MnO } \\
\text { (wt-\%) }\end{array}$ & $\begin{array}{l}\mathrm{H}_{2} \mathrm{O} \\
\text { (wt- } \\
\% \text { ) }\end{array}$ & $\mathrm{Sm}(\mathrm{ppm})$ & $\mathrm{Gd}(\mathrm{ppm})$ & $\begin{array}{l}\mathrm{K}_{2} \mathrm{O} \\
\text { (wt- } \\
\%)\end{array}$ & $\begin{array}{l}\mathrm{CaO} \\
\text { (wt- } \\
\% \text { ) }\end{array}$ & $\mathrm{Cl}(\mathrm{ppm})$ & $\begin{array}{l}\mathrm{TiO}_{2} \\
\text { (wt-\%) }\end{array}$ & $\begin{array}{l}\mathrm{Fe}_{2} \mathrm{O}_{3} \\
(w t-\%)\end{array}$ & $\begin{array}{l}\mathrm{P}_{2} \mathrm{O}_{5} \\
\text { (wt-\%) }\end{array}$ & $\mathrm{U}(\mathrm{ppm})$ & Th (ppm) & $\mathrm{Li}(\mathrm{ppm})$ \\
\hline Pico 4 & 64.26 & 4.22 & 2.38 & 15.58 & 0.08 & 0.5 & 4.3 & 3.2 & 2.34 & 4.41 & 500 & 0.611 & 5.25 & 0.16 & 2.6 & 7.6 & 14 \\
\hline Pico 5 & 63.95 & 4.12 & 2.18 & 15.39 & 0.08 & 0.5 & 4.4 & 3.4 & 2.28 & 4.39 & 500 & 0.587 & 4.95 & 0.16 & 2.5 & 7.2 & 15 \\
\hline Pico 6 & 64.47 & 4.23 & 2.26 & 15.77 & 0.08 & 0.5 & 4.2 & 3.4 & 2.39 & 4.32 & 600 & 0.614 & 5.22 & 0.17 & 2.6 & 7.3 & 15 \\
\hline Pico 7 & 63.95 & 4.07 & 2.75 & 15.26 & 0.08 & 0.5 & 4.3 & 3.5 & 2.13 & 4.62 & 700 & 0.651 & 5.38 & 0.17 & 2.0 & 5.5 & 14 \\
\hline Pico 8 & 63.94 & 4.05 & 2.72 & 15.15 & 0.08 & 0.5 & 4.6 & 3.6 & 2.18 & 4.38 & 400 & 0.644 & 5.26 & 0.19 & 2.2 & 5.9 & 14 \\
\hline
\end{tabular}


Table 3

Concentrations of the ${ }^{36} \mathrm{Cl}$ target elements, measured in splits taken from the samples after the chemical pre-treatment (see text). Analyses done at Activation Laboratories (Ancaster, Canada).

\begin{tabular}{lllll}
\hline Sample & $\mathrm{CaO} \%$ & $\mathrm{~K} 2 \mathrm{O} \%$ & $\mathrm{TiO} 2 \%$ & $\mathrm{Fe} 2 \mathrm{O} 3 \%$ \\
\hline & & & & \\
Pico 4 & 3.92 & 2.56 & 0.71 & 4.93 \\
Pico 5 & 3.74 & 2.59 & 0.62 & 4.65 \\
Pico 6 & 3.73 & 2.66 & 0.64 & 4.83 \\
Pico 7 & 4.72 & 2.63 & 0.74 & 5.74 \\
Pico 8 & 3.78 & 2.44 & 0.71 & 5.24
\end{tabular}

The nucleogenic and muonic scaling factors were calculated ac- cording to the time-invariant scaling model of Stone (2000), using CosmoCalc (Vermeesch, 2007), and applying the atmosphere standard model (N.O.A.A, 1976). When we apply the same scaling method but implementing a correction for the time-variant paleomagnetic field intensity, following the so-called "Lm" scaling approach in Balco et al. (2008), the resulting ${ }^{36} \mathrm{Cl}$ ages are older by $5-7 \%$. Moreover, the use of the local atmospheric pressure according to the ERA-40 model (Uppala et al., 2005) or inferred from the closest weather station (Loma Grande; $18.92 \mathrm{~N},-97.23 \mathrm{~W}, 2722 \mathrm{~m}$ a.s.I.) instead of the standard atmosphere pressure, together with the time-variant $\mathrm{Lm}$ scaling approach, yields ${ }^{36} \mathrm{Cl}$ ages older by $14-15 \%$ compared to the time-invariant Stone (2000) scaling. A high-energy attenuation length of $160 \mathrm{~g} \mathrm{~cm}^{-2}$ was applied. The shielding factors were calculated with the Topographic Shielding Calculator v1.0 provided by CRONUS-Earth Project (2014). A density of 2.5 $\mathrm{g} / \mathrm{cm}^{3}$ is assumed for all samples. Using a lower or higher density values $\left(2.3-2.8 \mathrm{~g} / \mathrm{cm}^{3}\right)$, the results would change by less than $1 \%$. Considering the good state of preservation of the sampled surfaces, no corrections for erosion were applied. Similarly, considering that today the snow pack usually remains only a few days during winter, the influence of the snow cover on the production rates when integrated over the last thousands of years is assumed to be insignificant (see further discussion in section 5). The $1 \sigma$ uncertainties associated with the ${ }^{36} \mathrm{Cl} C R E$ ages (Table 4 ) were calculated through full propagation of analytical and production rate errors. 
Table 4

Analytical ${ }^{36} \mathrm{Cl}$ data and resulting ${ }^{36} \mathrm{Cl} \mathrm{CRE}$ ages for samples from lava flows of Pico de Orizaba. Age uncertainties $(1 \sigma)$ include production rate errors as well as analytical errors; numbers in parenthesis correspond to analytical errors only.

\begin{tabular}{|c|c|c|c|c|c|c|c|}
\hline Sample & Sample weight (g) & Mass $\mathrm{Cl}(\mathrm{mg})$ added by spike & ${ }^{35} \mathrm{Cl} /{ }^{37} \mathrm{Cl}$ & ${ }^{36} \mathrm{Cl} /{ }^{35} \mathrm{Cl}\left(10^{14}\right)$ & $\mathrm{Cl}(\mathrm{ppm})$ & ${ }^{36} \mathrm{Cl}$ conc $\left(10^{3}\right.$ atoms $\left.\mathrm{g}^{-1}\right)$ & ${ }^{36} \mathrm{Cl}$ CRE age (ka) \\
\hline Pico 4 & 65.17 & 1.958 & $3.442 \pm 0.016$ & $9.11 \pm 0.50$ & $397 \pm 28$ & $511 \pm 43$ & $3.40 \pm 0.66(0.34)$ \\
\hline Pico 5 & 64.19 & 1.964 & $3.456 \pm 0.019$ & $7.35 \pm 0.40$ & $387 \pm 30$ & $403 \pm 36$ & $2.62 \pm 0.52(0.27)$ \\
\hline Pico 6 & 68.28 & 1.965 & $3.456 \pm 0.010$ & $8.83 \pm 0.43$ & $364 \pm 21$ & $456 \pm 32$ & $3.07 \pm 0.57(0.27)$ \\
\hline Pico 7 & 66.92 & 1.963 & $3.613 \pm 0.018$ & $5.63 \pm 0.35$ & $251 \pm 15$ & $209 \pm 17$ & $1.28 \pm 0.22(0.13)$ \\
\hline Pico 8 & 66.00 & 1.952 & $3.612 \pm 0.019$ & $6.49 \pm 0.43$ & $254 \pm 16$ & $243 \pm 21$ & $1.62 \pm 0.29(0.17)$ \\
\hline Blank & - & 1.956 & $377.4 \pm 9.4$ & $0.348 \pm 0.078$ & - & - & - \\
\hline
\end{tabular}

\subsection{Dendrochronology}

\subsubsection{Field sampling}

In order to estimate the minimum age of lava flow " $A$ " based on tree-ring counting, cross-sections from 32 individuals of the alpine woody shrub Juniperus monticola f. orizabensis Martínez from the side and top slopes of this lava flow, between 4140 and $4515 \mathrm{~m}$ a.s.l. (Fig. 2), were collected. Samples were taken by the use of a chain saw to cut across the main stem of dead specimens plants $(n=27)$ or a major branch of living but old-looking specimens $(n=5)$ (Fig. 5), pre- ferentially targeting cylindrical, symmetrical segments without growth disturbances. Due to the irregular growth pattern of rings, with nu- merous missing rings depending on the side of the trunk observed, samples from cores on living individuals were considered of limited use for dating purposes and therefore were not collected. The location of each sampled specimen was recorded in a GPS with a precision of $\pm 3 \mathrm{~m}$. Although Pinus hartwegii trees also grow on lava flow "A", they were not used for dating purposes as preliminary sampling showed that they are younger than 250 years.

\subsubsection{Laboratory analysis}

All samples were sanded with a belt sander with progressively finer sandpaper from 50 grits $(125-149 \mu \mathrm{m})$ to 400 grit $(20.6-23.6 \mu \mathrm{m})$ (Stokes and Smiley, 1968). Once the annual rings were clearly visible, growth rings were counted from the pit to the bark under the microscope at 40X magnification. Counts were performed along two per- pendicular lines on each cross section in order to compare and crossdate the dendrochronological series. Then, the growth rings were measured with a VELMEX measuring device (Robinson and Evans, 1980) at $0.001 \mathrm{~mm}$ resolution. We used the software COFECHA (Grissino-Mayer, 2001) to identify possible dating problems such as missing or false rings and to determine the dating quality.

\subsection{Lichenometry}

In this work, we used lichenometry on condition that the following criteria are met: (i) a volcano, although active, must not have had re- cent explosive activity (i.e. pyroclastic flows) that could have affected the lichen growth; (ii) under favorable environmental conditions, sur- faces of thousands of years can be dated by measuring the growth of lichens such as Rhizocarpon geographicum, a species that can colonize volcanic rocks on tropical mountains; and (iii) as lichenometry usually provides minimum ages, it should be combined with other dating methods.

Although lichenometry is a simple method, there is no agreement about how the thalli should be measured. For the lichen measurements in this work, we selected several sites close to the samples collected for ${ }^{36} \mathrm{Cl} \mathrm{CRE}$ dating and dendrochronology. We chose protruding features with smooth surfaces that were not fragmented or affected by volcanic or erosive processes after 


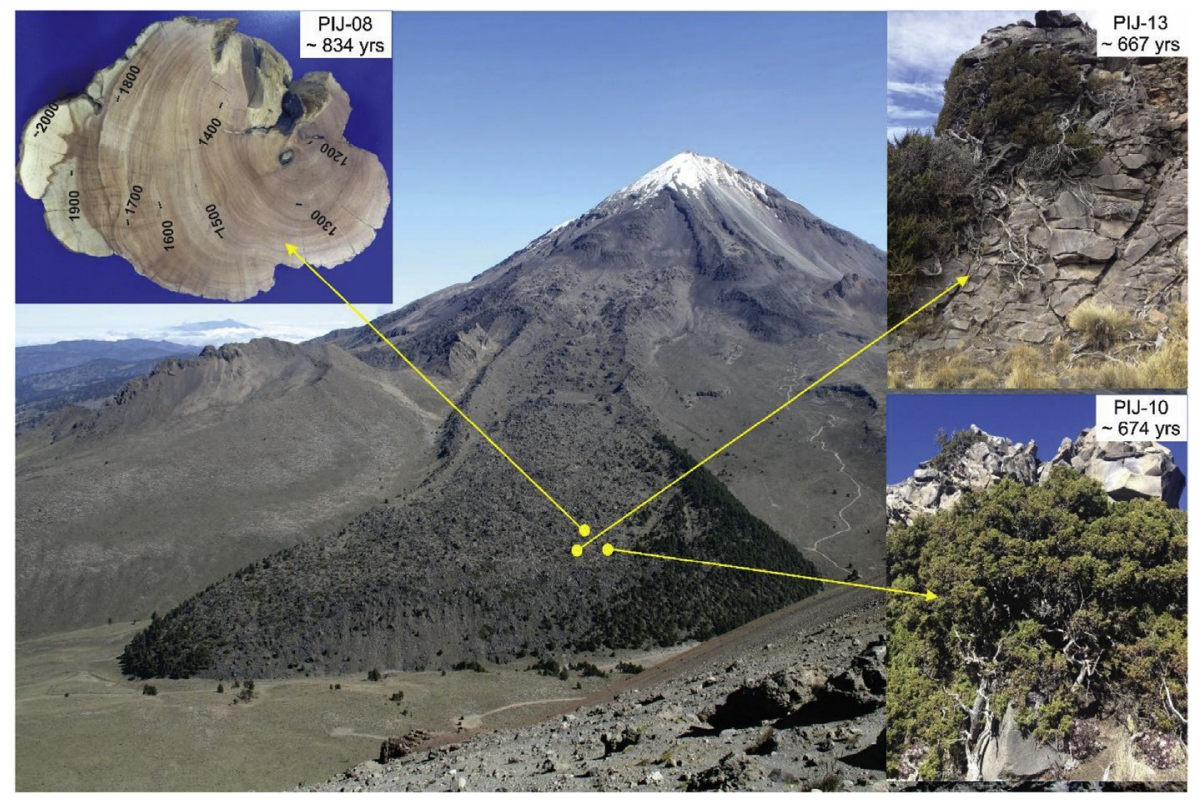

Fig. 5. Locations, characteristics and ages of the biggest individuals of Juniperus monticola f. orizabensis Martínez that grow on lava flow "A". One of them is older than 800 years and several individuals appear dead due to fires that affected the lowest area of the lava flow. 
Table 5

Dendrochronology-based ages of sampled individuals of Juniperus monticola $f$. Orizabensis Martínez growing on lava flow A. The lines

highlighted in green correspond to the oldest specimens recorded. Sampling took place in March 2015.

\begin{tabular}{|c|c|c|c|c|c|c|c|}
\hline Sample & Latitude & Longitude & $\begin{array}{l}\text { Altitude } \\
\text { (m. a.s.I) }\end{array}$ & $\begin{array}{l}\text { Innermost tree- } \\
\text { ring (AD year) }\end{array}$ & $\begin{array}{l}\text { Outermost tree- } \\
\text { ring (AD year) }\end{array}$ & $\begin{array}{c}\text { Age } \\
\text { (years) }\end{array}$ & Status \\
\hline PIJ-01 & 18.99 & -97.30 & 4143 & 1796 & 2014 & 218 & Live \\
\hline PIJ-02 & 18.99 & -97.30 & 4145 & 1643 & 2014 & 371 & Live \\
\hline PIJ-03 & 18.99 & -97.30 & 4147 & 1674 & 2014 & 340 & Live \\
\hline PIJ-04 & 18.99 & -97.30 & 4144 & 1582 & 1999 & 417 & Death \\
\hline PIJ-05 & 18.99 & -97.30 & 4144 & 1800 & 1992 & 192 & Death \\
\hline PIJ-06 & 18.99 & -97.30 & 4144 & - & - & 322 & Death \\
\hline PIJ-07 & 18.99 & -97.30 & 4147 & - & - & 304 & Death \\
\hline PIJ-08 & 18.99 & -97.30 & 4140 & 1178 & 2012 & 834 & Death \\
\hline PIJ-09 & 18.99 & -97.30 & 4150 & 1617 & 2009 & 392 & Death \\
\hline PIJ-10 & 18.99 & -97.30 & 4145 & 1325 & 1999 & 674 & Death \\
\hline PIJ-1I & 18.99 & -97.30 & 4157 & 1680 & 2009 & 329 & Death \\
\hline PIJ-12 & 18.99 & -97.30 & 4152 & 1619 & 2014 & 395 & Live \\
\hline PIJ-13 & 18.99 & -97.30 & 4149 & 1332 & 1999 & 667 & Death \\
\hline PIJ-14 & 18.99 & -97.30 & 4149 & - & - & 214 & Death \\
\hline PIJ-15 & 18.99 & -97.30 & 4154 & 1364 & 2000 & 636 & Death \\
\hline PIJ-16 & 18.99 & -97.30 & 4155 & 1527 & 1876 & 349 & Death \\
\hline PIJ-17 & 18.99 & -97.30 & 4153 & 1520 & 2004 & 484 & Death \\
\hline PIJ-18 & 18.99 & -97.30 & 4156 & 1672 & 2004 & 332 & Death \\
\hline PIJ-19 & 18.99 & -97.30 & 4153 & 1600 & 2000 & 400 & Death \\
\hline PIJ-20 & 18.99 & -97.30 & 4145 & 1390 & 1999 & 609 & Death \\
\hline PIJ-21 & 19.00 & -97.29 & 4226 & - & - & 243 & Death \\
\hline PIJ-22 & 19.00 & -97.29 & 4217 & - & - & 306 & Death \\
\hline PIJ-23 & 19.00 & -97.29 & 4337 & 1418 & 2014 & 596 & Live \\
\hline PIJ-24 & 19.01 & -97.29 & 4326 & 1740 & 2000 & 260 & Death \\
\hline PIJ-25 & 19.01 & -97.29 & 4268 & 1487 & 2000 & 513 & Death \\
\hline PIJ-26 & 19.01 & -97.29 & 4263 & 1700 & 1999 & 299 & Death \\
\hline PIJ-27 & 19.01 & -97.29 & 4270 & 1896 & 2008 & 112 & Death \\
\hline PIJ-28 & 19.01 & -97.29 & 4268 & - & - & 230 & Death \\
\hline PIJ-29 & 19.01 & -97.29 & 4267 & - & - & 261 & Death \\
\hline PIJ-30 & 19.01 & -97.29 & 4259 & 1745 & 1999 & 254 & Death \\
\hline PIJ-31 & 19.01 & -97.29 & 4242 & 1716 & 2000 & 284 & Death \\
\hline PIJ-32 & 19.00 & -97.29 & 4246 & - & - & 254 & Death \\
\hline
\end{tabular}

cooling. At each measurement site, the largest diameter of the at least 5 biggest circular thalli of Rhizocarpon geo- graphicum were measured with a Bernier calibrator. Digital photographs parallel to the surface of the lichen were taken, using a scale (one peso coin of $21 \mathrm{~mm}$ of diameter). Because the dated features are lava flows, there is no possibility of inheritance of thalli as may occur on sedi- mentary deposits. This criterion has usually been applied in volcanic environments and has been validated by the analysis of artificial sur- faces with a known age (Burbank, 1981; Porter, 1981; O'Neal, and Schoenenberger, 2003; O'Neal et al., 2013).

To determine the age of the largest lichen at each point, we used a growth rate of $0.23 \mathrm{~mm} \mathrm{a}^{-1}$ for Rhizocarpon geographicum established by Palacios et al. (2012) on Iztaccíhuatl volcano, $150 \mathrm{~km}$ to the west of Pico de Orizaba and at an altitude similar to that of the present study area. Detailed fieldwork analyzing lichens on deglaciated surfaces of known age by photogrammetry was conducted at the Pico de Orizaba. It confirmed the growth rate obtained at the Iztaccíhuatl volcano. We do not use the significantly higher $\left(0.6 \mathrm{~mm} \mathrm{a}^{-1}\right)$ growth rate of Rhizo- carpon geographicum reported from the Volcán Barú, Panamá (Zotz, 2017), since they were derived from sites at lower elevation (3350-3450 m a.s.I) and with higher precipitation. 


\subsection{Geomorphological map}

The geomorphological map (Fig. 2) show that the upper part of the Lava flow " $A$ " is covered by a pyroclastic layer, indicating explosive activity likely associated with the growth and destruction of domes sometime after its emission. Moreover, most of the surface of the lava flow "A" is formed by tumuli features and its edge has levees and steep lava fronts. Regarding Lava flow "B", it is formed by two superimposed flows. Due to their similar size, morphology (well-preserved blocky flows with lateral levees, rugged top surfaces and steep fronts) and thickness, they likely were emitted during the same volcanic event. Both flows are partially covered by proluvial-diluvial surfaces, debris flows and debris sheets. Around Lava flows "A" and "B, old volcanic structures, volcanic slopes covered by a pyroclastic layer, pyroclastic flow deposits and slopes affected by glacial erosion were identified.

\subsection{In situ-produced ${ }^{36} \mathrm{Cl}$ CRE dating}

The ${ }^{36} \mathrm{Cl}$ CRE ages of the southwestern lava flows of Pico de Orizaba are shown in Table 4. The three CRE ages from the lava flow "A" range from $3.40 \pm 0.66 \mathrm{ka}$ to $2.62 \pm 0.52 \mathrm{ka}$, whereas the two samples from the lava flow "B" lead to CRE ages of $1.28 \pm 0.22 \mathrm{ka}$ and $1.62 \pm 0.29 \mathrm{ka}$. The $17-20 \%$ uncertainty associated with the ${ }^{36} \mathrm{Cl}$ CRE ages result from the high natural chlorine concentration of $250-400 \mathrm{ppm}$ in the lava flow samples. It implies $\mathrm{a}^{36} \mathrm{Cl}$ contribution of $\sim 61-71 \%$ from a Cl- related ${ }^{36} \mathrm{Cl}$ production reaction, i.e. the capture of low-energy (i.e. thermal and epithermal) neutrons of cosmogenic origin on ${ }^{35} \mathrm{Cl}$ (Phillips et al., 2001). Due to the complexity of this production reaction and its dependency on various sample-specific environmental and surfacere- lated factors (e.g. snow cover, surface geometry; Zreda et al., 1993; Masarik et al., 2007; Dunai et al., 2014, section 5), which are difficult to accurately estimate, we assigned a conservative $30 \%$ uncertainty to the ${ }^{36} \mathrm{Cl}$ contribution from this production reaction pathway (Schimmelpfennig et al., 2009). The ${ }^{36} \mathrm{Cl}$ contribution from capture of non-cosmogenic low-energy neutrons (i.e. those related to the a-decay of the local $\mathrm{U}-\mathrm{Th}$ ) on ${ }^{35} \mathrm{Cl}$ is insignificant due to the young age of these igneous rocks; it is estimated to $<0.2 \%$ of the total ${ }^{36} \mathrm{Cl}$ production. The contribution from the better understood ${ }^{36} \mathrm{Cl}$ production from spallation of $\mathrm{Ca}, \mathrm{K}, \mathrm{Fe}$ and $\mathrm{Ti}$ amounts to $\sim 28-37 \%$ of the total ${ }^{36} \mathrm{Cl}$ production. In particular, the ${ }^{36} \mathrm{Cl}$ contribution from spallation of Ca of only $7-11 \%$ explains why the choice of the ${ }^{36} \mathrm{Cl}$ production rate from spallation of Ca does not significantly affect the calculated ${ }^{36} \mathrm{Cl} \mathrm{CRE}$ ages (see section 3.1.2.). The ${ }^{36} \mathrm{Cl}$ contribution from the capture of slow negative muons is estimated to less than $1 \%$.

Considering their associated analytical uncertainties (Table 4), the three ${ }^{36} \mathrm{Cl} \mathrm{CRE}$ ages from lava flow "A" and the two ages from lava flow "B" are not significantly different, respectively, as verified

by the $X^{2}$ test proposed in Ward and Wilson (1978), considering the 95\% confidence interval $(2 \sigma)$. This allows us to calculate arithmetic ${ }^{36} \mathrm{Cl}$ CRE mean age of $3.03 \pm 0.70$ ka for flow A and $1.45 \pm$ 0.35 ka for flow B (Table 7). The uncertainties associated with these ${ }^{36} \mathrm{Cl} C R E$ mean ages include the standard deviations as well as the analytical and production rate errors quadratically propagated. Calculating mean ages that are weighted by their inverse variances $\left(1 / \sigma^{2}\right)$, considering the full (i.e. analytical and production rate) errors in the individual ages, results in ages that are similar to the arithmetic means: $2.97 \pm 0.33$ ka for flow $A$ and

$1.40 \pm 0.18$ ka for flow $B$. 


\subsection{Dendrochronology}

The ages of 32 specimens of Juniperus monticola from lava flow "A" ranged from 112 to 834 years (Figs. 5 and 8 and Table 5); six specimens were older than 600 years (PIJ-08; PIJ-10; PIJ-13; PIJ15; PIJ-20). The precise date of the youngest ring of death specimens was determined by comparing their growth patterns with those of living specimens. The oldest specimen (PIJ-08) comes from $4140 \mathrm{~m}$ a.s.I., has 834 growth rings and lived from 1178 CE (innermost ring) to 2012 CE (outermost ring). The youngest one (PIJ-27), with 112 growth rings, grew from 1898 CE to 2008 $\mathrm{CE}$ at $4270 \mathrm{~m}$ a.s.I. Sampling took place in March 2015, whereby the outermost ring of living specimens is from $2014 \mathrm{CE}$. The outermost ring of $41 \%$ of the dead specimens formed in $1999 \mathrm{CE}$ and $2000 \mathrm{CE}$, probably as a result of extensive fires recorded in 1998 in connection with a strong EI Niño event. On the basis of the age of the oldest sample, we conclude that lava flow " $A$ " was already in place by $1178 \mathrm{CE}$.

\subsection{Lichenometry}

At the front of lava flow "A", between 4140 and $4170 \mathrm{~m}$ a.s.l., 4 measurement sites (Sites-1, 2, 3 and 4) close to the tree stands of Pinus hartwegii were established (Fig. 2). A high biodiversity of lichens and bryophytes showing a strong competition between them was observed at the lower sites (Site 1 and 2). However, this competition significantly decreased towards the higher sites (Sites 3 and 4) where thalli of Rhi- zocarpon geographicum grow extensively. At sites 3 and 4, thalli of Rhizocarpon geographicum with ages ranging between 185 and 720 years were found. By contrast, the most external and highest sites (Sites-11, 12, 13 and 14), on the left levee of lava flow "A" at 4400-4500 m a.s.I., present colonies formed by several long-lived individuals whose ages may reach 1000 years. The oldest thallus lead to an age of 1130 years (Figs. 6 and 8 and Table 6).

Lichens were measured at 6 sites along lava flow "B". Two of them (Sites 5 and 6 ) are located between 5000 and $4800 \mathrm{~m}$ a.s.I., where the lava flow starts, and the four others (Sites 7, 8, 9 and 10) are located between at 4590-4570 $\mathrm{m}$ a.s.I., close to the front. The two higher sites (Sites 5 and 6 ) only present small lichens with a maximum age of 400 years due to the presence of a pumice sheet, which partially covers the lava flow, and to a remarkable competition with bryophytes. At lower altitudes, i.e. at Sites 7, 8, 9 and 10, the lichens are more abundant. There, the ages of the biggest thalli, found on well-exposed surfaces (where competition with other species decreases), exceed 1000 years. The largest thallus lead to an age of 1090 years (Figs. 7 and 8 and Table 6). 


\section{Discussion}

The arithmetic ${ }^{36} \mathrm{Cl} C R E$ mean age of $3.03 \pm 0.70$ ka calculated from the three lava flow " $A$ " samples is $\sim 2$ ka older than the minimum ages provided by the oldest thalli of Rhizocarpon geographicum $(\sim 1.13$ $\mathrm{ka})$ and by the tree rings of Juniperus monticola ( $\sim 0.834 \mathrm{ka})$ (Table 7$)$. This difference indicates that the oldest individuals of Rhizocarpon geographicum and Juniperus monticola most probably do not correspond to the first colonization phase of both species. This may be due to the impact of fires, the volcanic activity or the natural mortality in a pio- neering community (Loso and Doak, 2006). Indeed, evidence of recent fires is observed in the lower part of the lava flow where only young specimens of Rhizocarpon geographicum are present. On the other hand, the presence of larger thalli in the lowest part of lava flow "A" may be limited due to the competition of Rhizocarpon geographicum with other species of lichens or bryophytes related to milder environmental con- ditions at lower elevation compared to those in the upper part of the lava flow. Moreover, a pyroclastic flow deposit partially covers the highest part of the lava flow, indicating explosive activity after the emission of the lava flow. Thus, pyroclastic flows most likely have burned/buried individuals of Rhizocarpon geographicum and Juniperus monticola colonizing the highest areas of the lava flow. In contrast, the lateral levees, less affected by the pyroclastic flows, apparently acted as a refuge for both species. However, despite these local constraints in pioneering colonization, the similar ages of the oldest individual of Rhizocarpon geographicum and Juniperus monticola provide a consistent minimum age supporting the ${ }^{36} \mathrm{Cl} \mathrm{CRE}$ mean age. The three performed methods clearly indicate that lava flow "A" was emplaced substantially earlier than the mid-16th century as was previously assumed, based on stratigraphy and correlation with historical records (Höskuldsson and Robin, 1993; Carrasco-Núñez, 1997). The ${ }^{36} \mathrm{Cl} \mathrm{CRE}$ ages calculated for the lava flow "B" samples (Pico 7 and 8) lead to an arithmetic mean of 1.45 \pm 0.35 ka. This ${ }^{36} \mathrm{Cl}$ CRE mean age cannot be compared with dendrochronology as the lava flow is located above $4500 \mathrm{~m}$ a.s.I., an elevation at which Juniperus monticola cannot grow. Moreover, thalli of Rhizocarpon geographicum are scarce and small due to debris sheets that covered the inner surface of the upper lava flow. However, four well defined and homogeneous thalli larger than $215 \mathrm{~mm} \quad(\sim 1000$ years) were found in the levees of the lower flow (Fig. 7). The morphology, ${ }^{36} \mathrm{Cl} \mathrm{CRE}$ ages and lichenometry are similar in both flows and therefore they probably were emitted during the same volcanic event. The ages obtained from both dating methods are consistent within uncertainties, which illustrates their usefulness in dating young landforms. Thus, lava flow "B" was emplaced between $~ 1800$ and $\sim 1000 \mathrm{yr}$ BP that is sev- eral hundred years before the eruptive episode of $1613 \mathrm{CE}$ to which it was associated by Höskuldsson and Robin (1993) and Carrasco-Núñez (1997). Therefore, the lava flow "A" ${ }^{36} \mathrm{Cl} C R E$ mean age of $3.03 \pm 0.70$ ka suggests that the corresponding eruption might be related to the Jacal (3450-3400 yr ago) eruptive episode described for the Pico de Orizaba by Höskuldsson and Robin (1993). Based on the lava flow "B" ${ }^{36} \mathrm{Cl}$ CRE mean age of $1.45 \pm 0.35 \mathrm{ka}$, the corresponding eruption can tentatively be associated with the Texmola (1910-1860 years BP) eruptive episode (Höskuldsson and Robin, 1993). Such as these lava flows are not of the 16th and 17th century eruptions, the lava flows related with these historical volcanic activity could be located on the northern flank of the volcano around the crater. Although the un-certainties associated with the presented data hinder us so far to establish a better-resolved chronology, the combination of ${ }^{36} \mathrm{Cl} \mathrm{CRE}$ dating, lichenometry and dendrochronology as performed in this study provides a useful approach to constrain lava flow emplacement ages. 


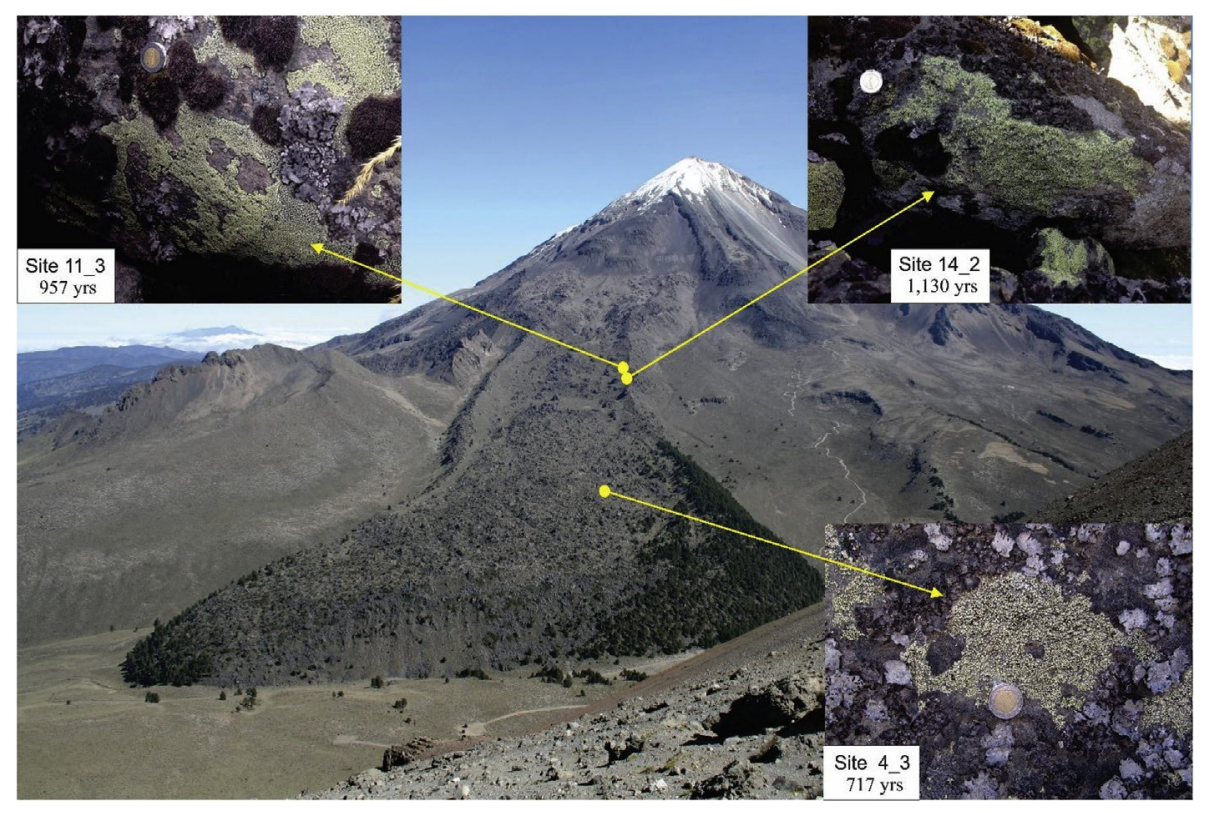

Fig. 6. Locations, characteristics and ages obtained from the biggest lichens found on lava flow "A". The thalli of Rhizocarpon geographicum located at the lowest area of the lava flow have a smaller size than the individuals that grow on the upper part of the levees of the lava flow due to the effect of fires.

A possible limitation that could affect the ${ }^{36} \mathrm{Cl} \mathrm{CRE}$ ages is related to the high concentrations of ${ }^{35} \mathrm{Cl}$ measured in the five rock samples (section 4.1 ). The ${ }^{36} \mathrm{Cl}$ accumulation in these samples is therefore significantly affected by the thermal and epithermal neutron flux, which is captured by ${ }^{35} \mathrm{Cl}$ to produce ${ }^{36} \mathrm{Cl}$. This flux has a high sensitivity 1 ) to the concentration of hydrogen (snow cover or pore water in the rock or soil surface) in the environment and it is still investigated how to correctly model the effect of hydrogen on the different cosmo- genic nuclide production reactions of ${ }^{36} \mathrm{Cl}$ (Masarik et al., 2007; Zweck et al., 2013; Dunai et al., 2014; Delunel et al., 2014) and 2) to the geometry of the rock surface (Zreda et al., 1993) (section 4.1). Today, the presence of water and snow in Pico de Orizaba mainly occurs during the wet season (May-October) and during some weeks in winter, when cold fronts from higher latitudes reach the study area. During episodes of different climate conditions over the last millennia, such as the Little Ice Age, the annual snow cover might have differed from today. How- ever, it has been shown based on paleo-lake records (Rodriguez- Ramírez et al., 2015) that the Little Ice Age in Mexico was characterized by several long dry intervals ( 100-150 years) rather than by cold and wet conditions. Therefore, the effect of potential hydrogen concentra- tion variations on the ${ }^{36} \mathrm{Cl}$ production in the studied samples is assumed to have been negligible during the exposure duration to cosmic ray derived particles of the sampled surfaces. Nonetheless, we here tenta- tively estimate the effect of snow cover on the ${ }^{36} \mathrm{Cl}$ CRE ages of our samples, based on the quantification of the influence of a hydrogen-rich cover on cosmogenic nuclide production rates as a function of the thermal-neutron-related contribution to total nuclide production pro- posed in Fig. 7 of Dunai et al. (2014): conservatively assuming an an- nual snow cover of two months with a thickness of $2.5 \mathrm{~cm}$ water equivalent (i.e. a snow thickness of $\sim 10-20 \mathrm{~cm}$ ) and a $50 \%$ thermal- neutron-related ${ }^{36} \mathrm{Cl}$ contribution (i.e. the potential effect from the $20 \%$ epithermal-neutron-related ${ }^{36} \mathrm{Cl}$ contribution is ignored for a sample with a $70 \%$ ${ }^{36} \mathrm{Cl}$ contribution from low-energy neutrons) would result in ${ }^{36} \mathrm{Cl} \mathrm{CRE}$ ages younger by $\sim 12 \%$, which is within the global un- certainties assigned to our ages. As for the rock surface geometry, Zreda et al. (1993) and references herein suggest that the low-energy neutron flux below an 
irregularly shaped rock surface might be reduced by up to $30 \%$, due to neutron diffusion out of the rock into air. Thus, the pro- truding and irregular forms of the sampled boulders and tumuli features (section 3.1.1; Fig. 3) might in fact have had an effect on the Cl-related ${ }^{36} \mathrm{Cl}$ production and could therefore explain the differences between the nominal values of samples Pico 4 (3.40 ka), Pico 5 (2.62 ka) and Pico 6 (3.07 ka). The biggest thalli of Rhizocarpon geographicum found in the study area, characterized by well-defined and homogeneous size, do not confirm the assumption of Innes (1985) and Matthews and Trenbirth (2011), that they can reach a maximum age of only 500 years. The hypothesis of Miller (1973), Calkin and Ellis (1984) and Benedict (2009) that the thalli of this species can exceed as much as 3000 years, cannot directly be supported, either, with the here presented data. However, assuming that Rhizocarpon geographicum can become as old as 3000 years and that the lichen growth was not disturbed by fire or volcanic activity since the emplacement of lava flow B, a possible time lapse between the lava flow emplacement and the beginning of lichen growth, or ecesis interval, of a few hundred years at $4600 \mathrm{~m}$ a.s.I. (lava flow "B") might be suggested by the difference between the ${ }^{36} \mathrm{Cl} \mathrm{CRE}$ and lichenometric ages. This value is significantly higher than the ecesis interval of 0-3 years proposed by Larocque and Smith (2004) in British Columbia and García Sancho et al. (2011) in Tierra de Fuego. The ecesis time in the study area could be overestimated due to the natural mor- tality of the first colonizers (Loso and Doak, 2006) and also affected by lithology (volcanic rocks retain few water due to their permeability), climate (long dry season, November-April) and repeated volcanic ac- tivity. Thus, due to these biological and local environmental con- straints, the ecesis time of Rhizocarpon geographicum of a few hundred years seems too long at Pico de Orizaba. By contrast, the ecesis time of the alpine shrub Juniperus monticola is not known and cannot be in- ferred from this work.

\section{Conclusions}

Three surface dating methods indicate that lava flows previously considered as related to historic (mid 16th to early 17th century) eruptions of Pico de Orizaba are substantially older. Regarding lava flow "A", in situ-produced ${ }^{36} \mathrm{Cl} \mathrm{CRE}$ dating lead to $\mathrm{a}^{36} \mathrm{Cl} \mathrm{CRE}$ mean age of $3.03 \pm 0.70 \mathrm{ka}$, dendrochronology based on the alpine shrub Juniperus monticola leads to a minimum age of 834 years, while liche- nometry of Rhizocarpon geographicum indicates a minimum age of 1130 years. Regarding lava flow "B", in situ-produced cosmogenic ${ }^{36} \mathrm{Cl} C R E$ dating lead to $a^{36} \mathrm{Cl} C R E$ mean age of $1.45 \pm 0.35 \mathrm{ka}$ and lichenometry leads to an age of $\sim 1000$ years. Although dendrochronology and lichenometry only provide minimum ages compared to ${ }^{36} \mathrm{Cl} \mathrm{CRE}$ dating, these two methods bear the potential to directly date lava flows of up to $\sim 800$ years using the tree species Juniperus monticola and up to $\sim 1000$ years using the lichen species Rhizocarpon geographicum, respectively. Overall, the combination of in situ-produced ${ }^{36} \mathrm{Cl} \mathrm{CRE}$ dating, licheno- metry and dendrochronology constitutes a pertinent approach to date young lava flows at high elevation sites where other methods are unsuitable and, thus, to refine the eruptive history of other volcanoes on Earth. 
Table 6

Field data and ages of thalli of Rhizocarpon geographicum growing on lava flows $A$ and $B$. The lines high- lighted in green correspond to thalli older than 900 years. Measurements took place in March 2015 and May-June 2016.

\begin{tabular}{|c|c|c|c|c|c|c|}
\hline Sample & Lava flow & Latitude & Longitude & $\begin{array}{l}\text { Altitude } \\
\text { (m.a.s.I.) }\end{array}$ & $\begin{array}{c}\text { Diameter } \\
(\mathrm{mm})\end{array}$ & Age (years) \\
\hline Site 1.1 & Lava A & 18.99 & -97.30 & 4144 & 46 & 200 \\
\hline Site 1.2 & Lava A & 18.99 & -97.30 & 4144 & 42 & 185 \\
\hline Site 1.3 & Lava A & 18.99 & -97.30 & 4144 & 43 & 190 \\
\hline Site 1.4 & Lava A & 18.99 & -97.30 & 4144 & 52 & 225 \\
\hline Site 1.5 & Lava A & 18.99 & -97.30 & 4144 & 67 & 290 \\
\hline Site 1.6 & Lava A & 18.99 & -97.30 & 4144 & 56 & 245 \\
\hline Site 1.7 & Lava A & 18.99 & -97.30 & 4144 & 87 & 380 \\
\hline Site 2.1 (a) & Lava A & 18.99 & -97.30 & 4143 & 65 & 285 \\
\hline Site 2.1 (b) & Lava A & 18.99 & -97.30 & 4143 & 58 & 250 \\
\hline Site 2.2 & Lava A & 18.99 & -97.30 & 4143 & 56 & 245 \\
\hline Site 2.3 & Lava A & 18.99 & -97.30 & 4143 & 92 & 400 \\
\hline Site 2.4 & Lava A & 18.99 & -97.30 & 4143 & 51 & 220 \\
\hline Site 3.1 & Lava A & 19.00 & -97.30 & 4158 & 152 & 660 \\
\hline Site 3.2 & Lava A & 19.00 & -97.30 & 4158 & 154 & 670 \\
\hline Site 3.3 & Lava A & 19.00 & -97.30 & 4158 & 127 & 550 \\
\hline Site 3.4 & Lava A & 19.00 & -97.30 & 4158 & 83 & 360 \\
\hline Site 3.5 & Lava A & 19.00 & -97.30 & 4158 & 164 & 715 \\
\hline Site 4.1 & Lava A & 19.00 & -97.30 & 4165 & 143 & 620 \\
\hline Site 4.2 & Lava A & 19.00 & -97.30 & 4165 & 124 & 540 \\
\hline Site 4.3 & Lava A & 19.00 & -97.30 & 4165 & 165 & 720 \\
\hline Site 4.4 & Lava A & 19.00 & -97.30 & 4165 & 75 & 325 \\
\hline Site 4.5 & Lava A & 19.00 & -97.30 & 4165 & 125 & 545 \\
\hline Site 5.1 & Lava B & 19.02 & -97.27 & 4935 & 23 & 100 \\
\hline Site 5.2 & Lava B & 19.02 & -97.27 & 4935 & 26 & 115 \\
\hline Site 5.3 & Lava B & 19.02 & -97.27 & 4935 & 90 & 390 \\
\hline Site 5.4 & Lava B & 19.02 & -97.27 & 4935 & 37 & 160 \\
\hline Site 6.1 & Lava B & 19.01 & -97.27 & 4831 & 37 & 160 \\
\hline Site 6.2 & Lava B & 19.01 & -97.27 & 4831 & 35 & 150 \\
\hline Site 6.3 & Lava B & 19.01 & -97.27 & 4831 & 74 & 320 \\
\hline Site 6.4 & Lava B & 19.01 & -97.27 & 4831 & 83 & 360 \\
\hline Site 7.1 & Lava B & 19.01 & -97.27 & 4589 & 143 & 620 \\
\hline Site 7.2 & Lava B & 19.01 & -97.27 & 4589 & 130 & 565 \\
\hline Site 7.3 & Lava B & 19.01 & -97.27 & 4589 & 98 & 425 \\
\hline Site 7.4 & Lava B & 19.01 & -97.27 & 4589 & 109 & 475 \\
\hline Site 7.5 & Lava B & 19.01 & -97.27 & 4589 & 102 & 445 \\
\hline Site 8.1 & Lava B & 19.01 & -97.27 & 4573 & 215 & 935 \\
\hline Site 8.2 & Lava B & 19.01 & -97.27 & 4573 & 139 & 605 \\
\hline Site 8.3 & Lava B & 19.01 & -97.27 & 4573 & 230 & 1000 \\
\hline Site 8.4 & Lava B & 19.01 & -97.27 & 4573 & 193 & 840 \\
\hline Site 9.1 & Lava B & 19.01 & -97.28 & 4577 & 235 & 1020 \\
\hline Site 9.2 & Lava B & 19.01 & -97.28 & 4577 & 155 & 675 \\
\hline Site 10.1 & Lava B & 19.01 & -97.28 & 4576 & 250 & 1090 \\
\hline Site 10.2 & Lava B & 19.01 & -97.28 & 4576 & 237 & 1030 \\
\hline Site 11.1 & Lava A & 19.01 & -97.28 & 4418 & 155 & 675 \\
\hline Site 11.2 & Lava A & 19.01 & -97.28 & 4418 & 93 & 405 \\
\hline Site 11.3 & Lava A & 19.01 & -97.28 & 4418 & 220 & 960 \\
\hline Site 11.4 & Lava A & 19.01 & -97.28 & 4418 & 100 & 435 \\
\hline Site 11.5 & Lava A & 19.01 & -97.28 & 4418 & 155 & 675 \\
\hline Site 12.1 & Lava A & 19.01 & -97.28 & 4448 & 195 & 850 \\
\hline Site 13.1 & Lava A & 19.01 & -97.28 & 4496 & 120 & 520 \\
\hline Site 13.2 & Lava A & 19.01 & -97.28 & 4496 & 155 & 675 \\
\hline Site 13.3 & Lava A & 19.01 & -97.28 & 4496 & 155 & 675 \\
\hline Site 13.4 & Lava A & 19.01 & -97.28 & 4496 & 120 & 520 \\
\hline Site 13.5 & Lava A & 19.01 & -97.28 & 4496 & 210 & 915 \\
\hline Site 13.6 & Lava A & 19.01 & -97.28 & 4496 & 130 & 565 \\
\hline Site 13.7 & Lava A & 19.01 & -97.28 & 4496 & 150 & 650 \\
\hline Site 13.8 & Lava A & 19.01 & -97.28 & 4496 & 150 & 650 \\
\hline Site 14.1 & Lava A & 19.01 & -97.29 & 4400 & 115 & 500 \\
\hline
\end{tabular}




$\begin{array}{lllllll}\text { Site } 14.2 & \text { Lava A } & 19.01 & -97.29 & 4400 & 260 & 1130 \\ \text { Site 14.3 } & \text { Lava A } & 19.01 & -97.29 & 4400 & 140 & 610 \\ \text { Site } 14.4 & \text { Lava A } & 19.01 & -97.29 & 4400 & 90 & 390 \\ \text { Site } 14.5 & \text { Lava A } & 19.01 & -97.29 & 4400 & 130 & 565 \\ \text { Site 14.6 } & \text { Lava A } & 19.01 & -97.29 & 4400 & 155 & 675\end{array}$




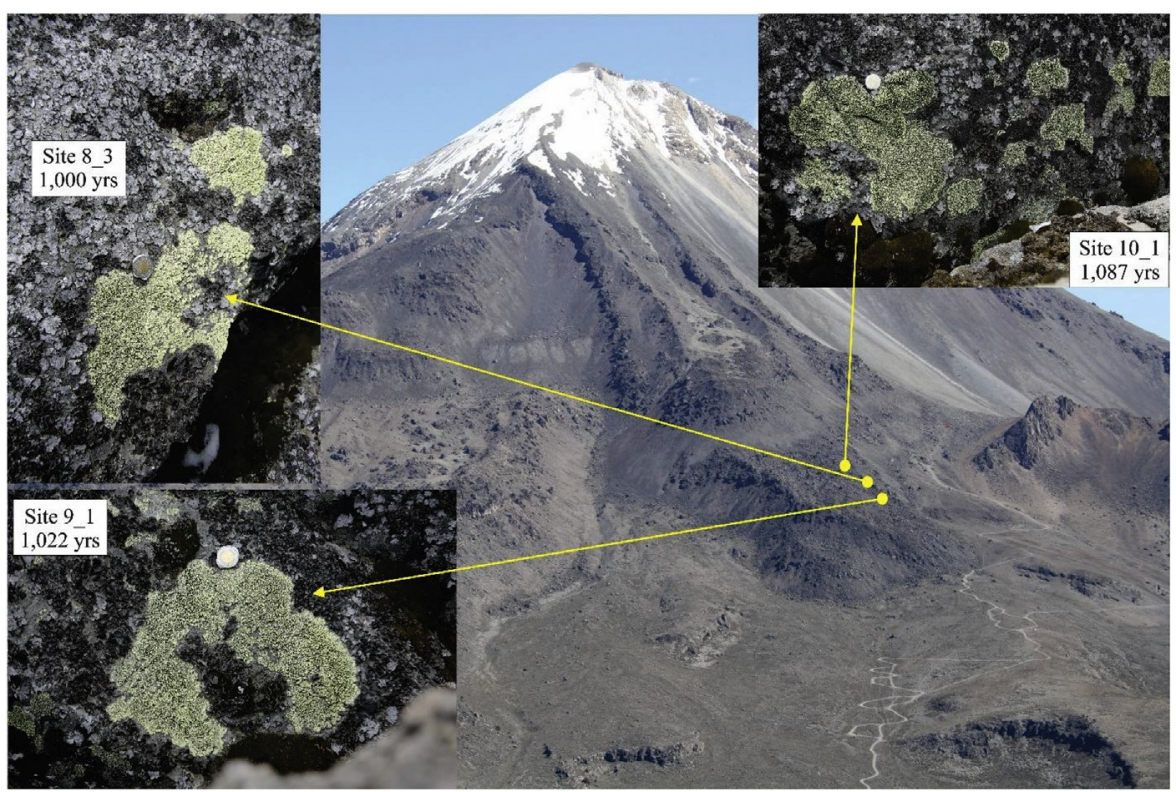

Fig. 7. Locations, characteristics and ages of the biggest lichens found on lava flow "B". Three of them lead to an age older than 1000 years.

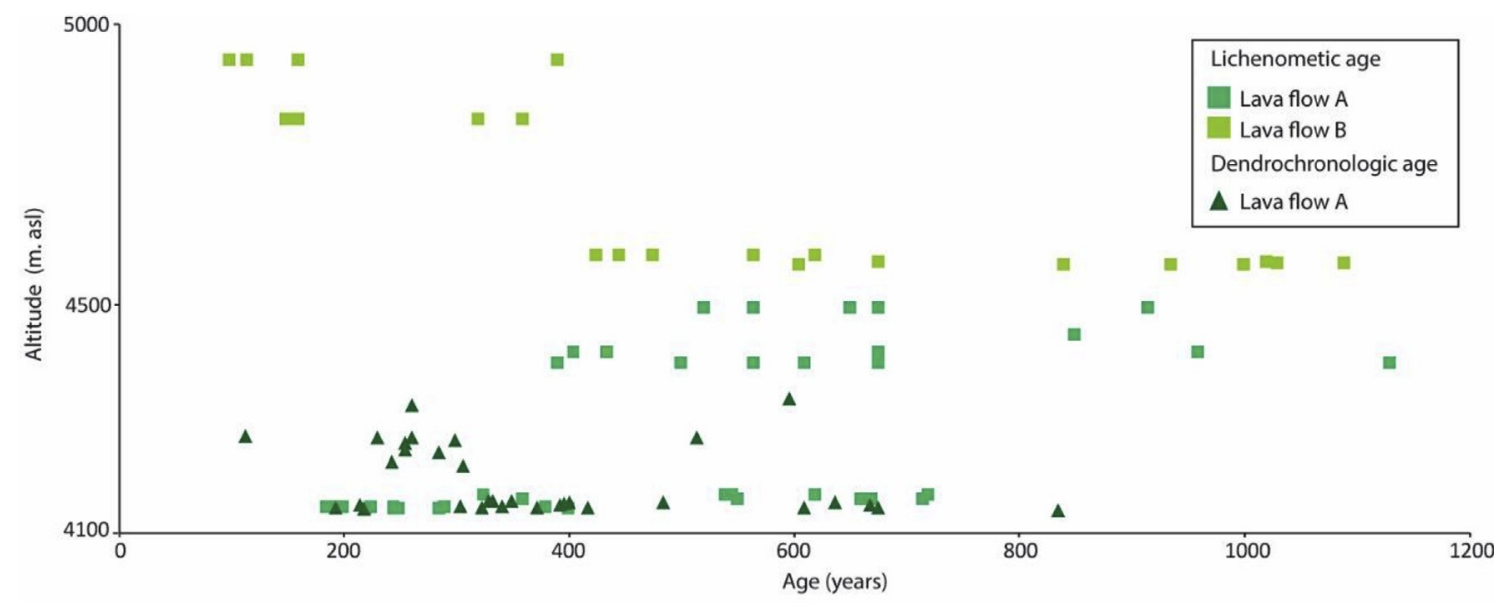

Fig. 8. Distribution of the ages of Rhizocarpon geographicum and Juniperus monticola depending on the altitude on lava flows " $A$ " and "B". 
Table 7

Ages of the lava flows $\mathrm{A}$ and $\mathrm{B}$ according to in situ-produced ${ }^{36} \mathrm{Cl}$ (arithmetic mean), lichenometry (oldest Rhizocarpon geographicum) and dendrochronology (oldest Juniperus monticola).

\begin{tabular}{llll}
\hline Lava flow & ${ }^{36} \mathrm{Cl}$ CRE age $(\mathrm{ka})$ & Lichenometry (ka) & Dendrochronology (ka) \\
\hline $\mathrm{A}$ & $3.03 \pm 0.70$ & 1.13 & 0.834 \\
$\mathrm{~B}$ & $1.45 \pm 0.35$ & 1.08 & - \\
\hline
\end{tabular}

\section{Acknowledgments}

The first author benefitted from a post-doctoral fellowship (DGAPA- UNAM). This research was supported by the Projects CGL2015-65813-R and CTM2015-64728-C2-1-R funded by the Spanish Ministry of Economy and Competitiveness and the Projects UNAM-DGAPA-PAPIIT grants IN105213 and IN109216. The ${ }^{36} \mathrm{Cl}$ measurements were per- formed at the ASTER AMS national facility (CEREGE, Aix en Provence) which is supported by the INSU/CNRS, the ANR through the "Projets thématiques d'excellence" program for the "Equipements d'excellence" ASTER-CEREGE action and IRD. We are grateful for the constructive comments by Romain Delunel and an anonymous reviewer, who greatly improved the manuscript.

\section{References}

Aciego, M.S., DePaolo, D.J., Kennedy, B.M., Lamb, M.P., Sims, K.W., Dietrich, E., 2007. Combining $\left({ }^{3} \mathrm{He}\right)$ cosmogenic dating with $\mathrm{U}-\mathrm{Th} / \mathrm{He}$ eruption ages using olivine in basalt. Earth Planet Sci. Lett. 254, 288-302.

Angiel, P.J., Dąbski, M., 2012. Lichenometric ages of the Little ice age moraines on king George island and of the last volcanic activity on Penguin island (west Antarctica). Geogr. Ann. Phys. Geogr. 94 (3), 395-412.

Armstrong, R.A., 2016. Lichenometric dating (lichenometry) and the biology of the lichen genus Rhizocarpon: challenges and future directions. Geogr. Ann. Phys. Geogr. 98, 183-206.

Arnold, M., Aumaître, G., Bourlès, D.L., Keddadouche, K., Braucher, R., Finkel, R.C., Nottoli, E., Benedetti, L., Merchel, S., 2013. The French accelerator mass spectro- metry facility ASTER after 4 years: status and recent developments on $36 \mathrm{Cl}$ and 129I. Nucl. Instrum. Meth. Phys. Res. 294, 24-28.

Balco, G., Stone, J.O., Lifton, N.A., Dunai, T.J., 2008. A complete and easily accessible means of calculating surface exposure ages or erosion rates from ${ }^{10} \mathrm{Be}$ and ${ }^{26} \mathrm{Al}$ measurements. Quat. Geochronol. 3, 174-195.

Bashenina, B., 1977. Geomorphological Mapping. High Level Education. URSS, Moscow (In Russian).

Beget, J.E., 1984. Tephrochronology of late Wisconsin deglaciation and Holocene glacier fluctuations near Glacier Peak, North Cascade range, Washington. Quat. Res. 21 (3), 304316.

Benedict, J.B., 2009. A review of lichenometric dating and its applications to archaeology. Am. Antiq. 143-172. 
Bradwell, T., Armstrong, R.A., 2007. Growth rates of Rhizocarpon geographicum lichens: a review with new data from Iceland. J. Quat. Sci. 2, 311-320.

Briner, J.P., 2011. Dating glacial landforms. In: Encyclopedia of Snow, Ice and Glaciers. Springer, Netherlands, pp. 175-176.

Bull, W.B., 2015. Lichenometry. In: Encyclopedia of Scientific Dating Methods, pp. 372-378 Shington, USA.

Burbank, D.W., 1981. A chronology of late Holocene glacier fluctuations on Mount Rainier, Washington. Arct. Alp. Res. 13 (4), 369-386.

Calkin, P.E., Ellis, J.M., 1984. Development and application of a lichenometric dating curve, Brooks Range, Alaska. Dev. Palaeontol. Stratigr. 7, 227-246.

Calvert, A.T., Moore, R.B., McGeehin, J.P., Rodrigues da Silva, A.M., 2006. Volcanic history and ${ }^{40} \mathrm{Ar} /{ }^{39} \mathrm{Ar}$ geochronology of Terceira island, azores, Portugal. J. Volcanol. Geoth. Res. 156, 103-115.

Carrasco-Núñez, G., Rose, W.I., 1995. Eruption of a major Holocene pyroclastic flow at Citlaltépetl volcano (Pico de Orizaba), México, 8.5-9.0 ka. J. Volcanol. Geoth. Res. 69, 197215.

Carrasco-Núñez, G., 1997. Lava flow growth inferred from morphometric parameters: a case study of Citlaltépetl volcano, Mexico. Geol. Mag. 134, 151-162.

Carrasco-Núñez, G., 2000. Structure and proximal stratigraphy of Citlaltépetl volcano (Pico de Orizaba), Mexico. Geol. Soc. Am. 334, 247-262.

Cerling, T.E., 1990. Dating geomorphologic surfaces using cosmogenic ${ }^{3}$ He. Quat. Res. 33, 148-156.

Clarkson, B.R., Clarkson, B.D., 1983. Mt. Tarawera: 2. Rates of change in the vegetation and flora of the high domes. New Zealand J. Ecol. 6, 107-119.

Conway, C.E., Townsend, D.B., Leonard, G.S., Wilson, C.J.N., Calvert, A.T., Gamble, J.A., 2015. Lava-ice interaction on a large composite volcano: a case study from Ruapehu, New Zealand. Bull. Volcanol. 77, 21.

Crandell, D.R., Mullineaux, D.R., Sigafoos, R.S., Rubin, M., 1974. Chaos crags eruptions and rockfall-avalanches, Lassen volcanic national park, California. US Geol. Surv. J. Res. 2, 4959.

Delunel, R., Bourlès, D.L., Van der Beek, P.A., Schlunegger, F., Leya, I., Masarik, J., Paquet, E., 2014. Snow shielding factors for cosmogenic nuclide dating inferred from long-term neutron detector monitoring. Quat. Geochronol. 24, 16-26.

Dunai, T.J., 2010. Cosmogenic nuclides. Principles, Concepts and Applications in the Earth Surface Sciences. Cambridge University Press, pp. 198.

Dunai, T.J., Binnie, S.A., Hein, A.S., Paling, S.M., 2014. The effects of a hydrogen-rich ground cover on cosmogenic termal neutrons: implications for exposure dating. Quat. Geochronol. 22, 183-191.

Dunbar, N.W., 1999. Cosmogenic ${ }^{36} \mathrm{Cl}$-determined age of the Carrizozo lava flows, southcentral New Mexico. N. M. Geol. 21 (2), 25-29.

Espanon, V.R., Honda, M., Chivas, A.R., 2014. Cosmogenic ${ }^{3} \mathrm{He}$ and ${ }^{21} \mathrm{Ne}$ surface exposure dating of young basalts from Southern Mendoza, Argentina. Quat. Geochronol. 19, 76-86.

Fenton, C.R., Niedermann, S., 2014. Surface exposure dating of young basalts (1-200 ka) in the San Francisco volcanic field (Arizona, USA) using cosmogenic ${ }^{3} \mathrm{He}$ and ${ }^{21} \mathrm{Ne}$. Quat. Geochronol. 19, 87-105.

Fink, D., Vogt, S., Hotchkis, M., 2000. Cross-sections for $36 \mathrm{Cl}$ from Ti at Ep $=35-150 \mathrm{MeV}$ : applications to in-situ exposure dating. Nucl. Instrum. Methods Phys. Res. Sect. B Beam Interact. Mater. Atoms 172, 861-866. 
Foeken, J., Stuart, F.M., Francalanci, L., 2009. Dating Holocene lavas on Stromboli, Italy using cosmogenic He. Quat. Geochronol. 4, 517-524.

Foeken, J., Stuart, F.M., Mark, D.F., 2012. Long-term low latitude cosmogenic ${ }^{3} \mathrm{He}$ pro- duction rate determined from a 126 ka basalt from Fogo, Cape Verdes. Earth Planet Sci. Lett. 359360, 14-25.

Franco-Ramos, O., Vázquez-Selem, L., Zamorano-Orozco, J.J., Villanueva-Díaz, J., 2017. Edad, dinámica geomorfológica y tipología de barrancas en el sector norte del volcán Popocatépetl, México. Bol. Soc. Geol. Mex. 69, 1-19.

García-Sancho, L., Palacios, D., Green, T.G.A., Vivas, M., Pintado, A., 2011. Extreme high lichen growth rates detected in recently deglaciated areas in Tierra del Fuego. Polar Biol. 34, 813-822.

Germa, A., Quidelleur, X., Gillot, P.Y., Tchilinguirian, P., 2010. Volcanic evolution of the blackarc Pleistocene Payun Matru volcanic field (Argentina). J. S. Am. Earth Sci. 29, 717-730.

Grissino-Mayer, H.D., 2001. Evaluating crossdating accuracy: a manual and tutorial for the computer program COFECHA. Tree-Ring Res. 57 (2), 205-221.

Heineke, C., Niedermann, S., Hetzel, R., Akal, C., 2016. Surface exposure dating of Holocene basalt flows and cinder cones in the Kula volcanic field (Western Turkey) using cosmogenic ${ }^{3} \mathrm{He}$ and ${ }^{10} \mathrm{Be}$. Quat. Geochronol. 34, 81-91.

Höskuldsson, A., Robin, C., 1993. Late Pleistocene to Holocene eruptive activity of Pico de Orizaba, Eastern Mexico. Bull. Volcanol. 55, 571-587.

Innes, J.L., 1985. An examination of some factors affecting the largest lichens on a sub- strate. Arct. Alp. Res. 17, 99-106.

Ivy-Ochs, S., Synal, H.A., Roth, C., Schaller, M., 2004. Initial results from isotope dilution for CI and ${ }^{36} \mathrm{Cl}$ measurements at the PSI/ETH Zurich AMS facility. Nucl. Instrum.

Methods Phys. Res. Sect. B Beam Interact. Mater. Atoms 223-224, 623-627.

Jomelli, V., Lane, T., Favier, V., Masson-Delmotte, V., Swingedouw, D., Rinterknecht, V., Schimmelpfennig, I., Brunstein, D., Verfaillie, D., Adamson, K., Leanni, L., Mokadem, F., Aumaitre, G., Bourles, D.L., Keddadouche, K., 2016. Paradoxical cold conditions during the medieval climate anomaly in the Western Arctic. Sci. Rep. 6, 32984. http://dx.doi.org/10.1038/srep32984.

Kirkbride, M.P., Dugmore, A.J., 2008. Two millennia of glacier advances from southern Iceland dated by tephrochronology. Quat. Res. 70 (3), 398-411.

Koch, J., Clague, J.J., Osborn, G.D., 2007. Glacier fluctuations during the past millennium in Garibaldi provincial park, southern coast mountains, British Columbia. Can. J. Earth Sci. 44, $1215-1233$.

Kurina, L.M., Vitousek, P.M., 1999. Controls over the accumulation and decline of a ni- trogenfixing lichen, Stereocaulon vulcani, on young Hawaiian lava flows. J. Ecol. 87 (5), 784-799. Kurz, M.D., Rowland, S.K., Curtice, J., Saal, A.E., Naumann, T., 2014. Eruption rates for Fernandina volcano: a new chronology at the Galápagos hotspot center. In: The Galapagos: a Natural Laboratory for the Earth Sciences, Geophysical Monograph 204, first ed. American Geophysical Union.

Larocque, S.J., Smith, D.J., 2004. Calibrated Rhizocarpon spp. Growth curve for the mount Waddington area, British Columbia coast mountains, Canada. Arctic Antarct. Alpine Res. 36, 407-418.

Lauer, W., 1978. Timberline studies in Central Mexico. Arct. Alp. Res. 10, 383-396.

Le Bas, M.J., Le Maitre, R.W., Streckeisen, A., Zanettin, B., 1986. A chemical classification of volcanic rocks based on the total alkali-silica diagram. J. Petrol. 27, 745-750.

Lescinsky, D.T., Fink, J.H., 2000. Lava and ice interaction at stratovolcanoes: use of 
characteristic features to determine past glacial extents and future volcanic hazards. J. Geophys. Res. 105, 23,711-23,726.

Loso, M.G., Doak, D.F., 2006. The biology behind lichenometric dating curves. Oecologia 147, 223-229.

Mancebo, J.M.G., Pinto, L.S., Tejera, E.B., Lima, A.L., 1989. Contribución al estudio florístico de las coladas históricas de las Islas Canarias. I: chinyero (Tenerife). An. del Jardín Botánico Madr. 46 (2), 437-444.

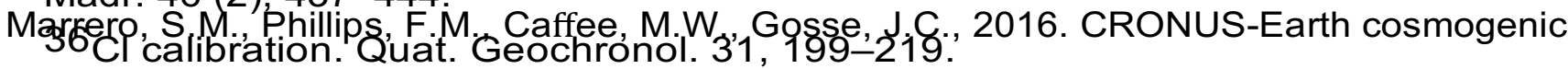

Masarik, J., Kim, K.J., Reedy, R.C., 2007. Numerical simulations of in situ production of terrestrial cosmogenic nuclides. Nucl. Instrum. Methods Phys. Res. Sect. B Beam Interact. Mater. Atoms 259, 642-645.

Matthews, J.A., Trenbirth, H.E., 2011. Growth rate of a very large crustose lichen (Rhizocarpon subgenus) and its implications for lichenometry. Geogr. Ann. Phys. Geogr. 93 (1), $27-39$.

Medynski, S., Pik, R., Burnard, P., Vye-Brown, C., France, L., Schimmelpfennig, I., Whaler, K., Johnson, N., Benedetti, L., Ayelew, D., Yirgu, G., 2015. Stability of rift axis magma reservoirs: spatial and temporal evolution of magma supply in the Dabbahu rift segment (Afar, Ethiopia) over the past 30 kyr. Earth Planet Sci. Lett. 409, 278-289.

Miller, G.H., 1973. Late quaternary glacial and climatic history of northern cumberland peninsula, Baffin island, NWT, Canada. Quat. Res. 3 (4), 561-583.

N.O.A.A, 1976. U.S. Standard Atmosphere. US Gov. Print. Off.

O'Neal, M.A., Schoenenberger, K.R., 2003. A Rhizocarpon geographicum growth curve for the Cascade Range of Washington and northern Oregon, USA. Quat. Res. 60, 233-241.

O'Neal, M.A., Legg, N.T., Hanson, B., Morgan, D.J., Rothgeb, A., 2013. Lichenometric dating of rock surfaces in the northern Cascade Range, USA. Geogr. Ann. Phys. Geogr. 95, 241248.

Palacios, L., García-Sancho, Zamorano, J.J., Andrés, N., Pintado, A., 2012. The degla- ciation of Iztaccíhuatl volcano (Mexico) from the Little lce Age maximum to the present, determined by photogrametry and lichenometry. Geophys. Res. Abstr. 14, EGU2012-3755 2012.

Phillips, F.M., Stone, W.D., Fabryka-Martin, J.T., 2001. An improved approach to cal- culating low-energy cosmic-ray neutron fluxes near the land/atmosphere interface. Chem. Geol. 175, 689-701.

Pierson, T.C., 2007. Dating young geomorphic surfaces using age of colonizing Douglas fir in southwestern Washington and northwestern Oregon, USA. Earth Surf. Process.

Landforms 32, 811-831.

Porter, S.C., 1981. Lichenometric studies in the cascade range of Washington: establish- ment of Rhizocarpon geographicum growth curves at mount Rainier. Arct. Alp. Res. 13 (1), 1123.

Renne, P.R., 2000. K-ar and ${ }^{40} \mathrm{Ar} /{ }^{39} \mathrm{Ar}$ Dating. Quaternary Geochronology: Methods and Applications. American Geophysical Union.

Robinson, W.J., Evans, R., 1980. A microcomputer-based tree ring measuring system. Tree-Ring Bull. 40, 59-64.

Rodriguez-Ramírez, A., Caballero, M., Roy, P., Ortega, B., Vázquez-Castro, G., LozanoGarcía, S., 2015. Climatic variability and human impact during the last 2000 years in western Mesoamerica: evidence of late Classic (AD 600-900) and Little Ice Age drought events. Clim. Past 11, 1239-1248.

Rossotti, A., Carrasco-Núñez, G., 2004. Stratigraphy of the 8.5-9.0 ka B.P. Citlaltépetl pumice fallout sequence. Rev. Mex. Ciencias Geol. 21, 353-370.

Schimmelpfennig, I., 2009. Cosmogenic ${ }^{36} \mathrm{Cl}$ in $\mathrm{Ca}$ and $\mathrm{K}$ Rich Minerals: Analytical Developments, Production Rate Calibrations and Cross Calibration with ${ }^{3} \mathrm{He}$ and ${ }^{21} \mathrm{Ne}$. 
Ph.D. Thesis. Paul Cezanne Aix-Marseille III University, Aix en Provence,

France.

Schimmelpfennig, I., Benedetti, L., Finkel, R., Pik, R., Blard, P.H., Bourle, D., Burnard, P.,

Williams, A., 2009. Sources of in-situ $36 \mathrm{Cl}$ in basaltic rocks. Implications for cali- bration of production rates. Quat. Geochronol. 4, 441-461.

Schimmelpfennig, I., Benedetti, L., Garreta, V., Pik, R., Blard, P.H., Burnard, P., Bourlès, D.,

Finkel, R., Ammon, K., Dunai, T., 2011. Calibration of cosmogenic ${ }^{36} \mathrm{Cl}$ production rates from

$\mathrm{Ca}$ and $\mathrm{K}$ spallation in lava flows from Mt. Etna $\left(38^{\circ} \mathrm{N}\right.$, Italy) and Payun Matru $\left(36^{\circ} \mathrm{S}\right.$,

Argentina). Geochem. Cosmochim. Acta 75, 2611-2632.

Schimmelpfennig, I., Schaefer, J.M., Akcar, N., Koffman, T., Ivy-Ochs, S., Schwartz, R., Finkel,

R.C., Zimmerman, S., Schlüchter, C., 2014. A chronology of Holocene and Little Ice Age glacier culminations of the Steingletscher, Central Alps, Switzerland, based on highsensitivity beryllium-10 moraine dating. Earth Planet Sci. Lett. 393, 220-230.

Schneider, B., Kuiper, K.F., Mai, K., Foeken, J.P.T., Stuart, F.M., Wijbrans, 2014.

Fuerteventura - assessment of a calibration site for cosmogenic ${ }^{3} \mathrm{He}$ exposure dating with the ${ }^{40} \mathrm{Ar} /{ }^{39} \mathrm{Ar}$ incremental heating method. Quat. Geochronol. 21, 58-69.

Sharma, P., Kubik, P.W., Fehn, U., Gove, H.E., Nishiizumi, K., Elmore, D., 1990.

Development of ${ }^{36} \mathrm{Cl}$ standards for AMS. Nucl. Instrum. Meth. Phys. Res. 52, 410-415.

Shimizu, A., 2004. Community structure of lichens in the volcanic highlands of Mt.

Tokachi, Hokkaido, Japan. Bryol. 107 (2), 141-151.

Shroder Jr., J.F., Butler, D.R., 1987. Tree ring analysis in the earth sciences. In: Jacoby Jr.G.C.,

Hornbeck, J.W. (Eds.), Proceedings of the International Symposium on Ecological Aspects of Tree-ring Analysis, Publication CONF-8608144. U.S. Department of Energy, Tarrytown, New York, pp. 186-212.

Siebe, C., Abrams, M., Sheridan, M.F., 1993. Major Holocene block-and-ash fan at the western slope of ice-capped Pico de Orizaba volcano, México: implications for future hazards. J. Volcanol. Geoth. Res. 59, 1-33.

Simonov, Yu G., 1972. Regional Geomorphological Analysis. Gos. Uni, Moscow: Mosk (In Russian).

Stokes, M.A., Smiley, T.L., 1968. An Introduction to Tree-ring Dating. The University of Arizona Press, Tucson, Arizona 73 pp.

Stone, J., 2000. Air pressure and cosmogenic isotope production. J. Geophys. Res. 105, 23,753-23,759.

Stone, J.O., Fifield, K., Vasconcelos, P., 2005. Terrestrial chlorine-36 production from spallation of iron. In: 10th International Conference on Accelerator Mass Spectrometry, Berkeley, USA.

Stoffel, M., Bollschweiler, M., Butler, D.R., Luckman, B.H., 2010. Tree rings and natural hazards-an introduction. In: Stoffel, M., Bollschweiler, M., Butler, D.R., Luckman,

B.H. (Eds.), Tree Rings and Natural Hazards: a State-of-the-art. Springer, Heidelberg, New York, pp. 495-502.

Talbot, S.S., Talbot, S.L., Walker, L.R., 2010. Post-eruption legacy effects and their implications for long-term recovery of the vegetation on Kasatochi Island, Alaska. Arctic Antarct. Alpine Res. 42 (3), 285-296.

Trumbore, S.E., 2000. Radiocarbon Geochronology. Quaternary Geochronology: Methods and Applications. American Geophysical Union.

Uppala, S.M., KÅllberg, P.W., Simmons, A.J., Andrae, U., Bechtold, V.D.C., Fiorino, M., Gibson, J.K., Haseler, J., Hernandez, A., Kelly, G.A., Li, X., Onogi, K., Saarinen, S., 
Sokka, N., Allan, R.P., Andersson, E., Arpe, K., Balmaseda, M.A., Beljaars, A.C.M., Van De Berg, L., Bidlot, J., Bormann, N., Caires, S., Chevallier, F., Dethof, A., Dragosavac, M., Fisher, M., Fuentes, M., Hagemann, S., Ho_Im, E., Hoskins, B.J., Isaksen, L., Janssen, P.A.E.M., Jenne, R., Mcnally, A.P., Mahfouf, J.-F., Morcrette, J.-

J., Rayner, N.A., Saunders, R.W., Simon, P., Sterl, A., Trenberth, K.E., Untch, A., Vasiljevic, D., Viterbo, P., Woollen, J., 2005. The ERA-40 Re-analysis. vol. 131. Quartely Journal of the Royal Meteorological Society, pp. 2961-3012. https://doi. org/10.1256/qj.04.176.

Vázquez-Selem, L., Heine, K., 2011. Late quaternary glaciation in Mexico. In: Ehlers, J., Gibbard, P.L., Hughes, P.D. (Eds.), Quaternary Glaciations - Extent and Chronology. A Closer Look. Elsevier, Amsterdam, pp. 849-861. http://doi.org/10.1016/B978-0- 444-534477.00061-1.

Vermeesch, P., 2007. CosmoCalc: an excel add-in for cosmogenic nuclide calculations. Gcubed 8, 1525-2027.

Villanueva-Díaz, J., Cerano, J., Vázquez Selem, L., Stahle, D.W., Fulé, P.Z., Yocom, L.L., Franco-Ramos, O., Ruiz Corral, J.A., 2015. Red dendrocronológica del pino de altura (Pinus hartwegii Lindl.) para estudios dendroclimáticos en el noreste y centro de México, vol. 86. Investigaciones Geográficas. Boletín del Instituto de Geografía, UNAM, pp. 5-14.

Villanueva-Díaz, J., Vázquez-Selem, L., Gómez-Guerrero, A., Cerano-Paredes, J., AguirreGonzález, N.A., Franco-Ramos, O., 2016. Dendrochronologic potential of Juniperus monticola Martínez in mount Tláloc, México. Rev. Fitotec. Mex. 39 (2), 175-185 ISSN $0187-$ 7380.

Ward, G.K., Wilson, S.R., 1978. Procedure for comparing and combining radiocarbon age determinations: a critique. Archaeometry 20, 19-31.

Wijbrans, J., Schneider, B., Kuiper, K., Calvari, S., Branca, S., De Beni, E., Norini, G., Corsaro, R.A., Miraglia, L., 2011. ${ }^{40} \mathrm{Ar} /{ }^{39} \mathrm{Ar}$ geochronology of Holocene basalts; ex- amples from Stromboli, Italy. Quat. Geochronol. 6, 223-232.

Zotz, G., 2017. Growth of Rhizocarpon geographicum in the summit region of volcán Barú, Panamá. Lichenol. 49, 535-538.

Zreda, M.G., Phillips, F.M., Kubik, P.W., Sharma, P., Elmore, D., 1993. Cosmogenic ${ }^{36} \mathrm{Cl}$ dating of a young basaltic eruption complex, Lathrop Wells, Nevada. Geology 21, 57-60.

Zweck, C., Zreda, M., Desilets, D., 2013. Snow shielding factors for cosmogenic nuclide dating inferred from Monte Carlo neutron transport simulations. Earth Planet Sci. Lett. 379, 64-71. 